\title{
Three-dimensional textural investigation of sulfide mineralisation from the Loolekop carbonatite-phoscorite polyphase intrusion in the Phalaborwa Igneous Complex (South Africa), with implications for ore-forming processes
}

\author{
Loic Y. Le Bras ${ }^{1 \star}$ (D), Robert Bolhar ${ }^{1}$, Lunga Bam², Bradley M. Guy ${ }^{3}$, Grant M. Bybee ${ }^{1}$ and Paul A.M. Nex ${ }^{1}$ \\ ${ }^{1}$ School of Geosciences, University of the Witwatersrand, Braamfontein 2001, Johannesburg, South Africa; ${ }^{2}$ South African Nuclear Energy Corporation SoC Ltd. \\ (Necsa), Elias Motsoaledi Street Ext. (Church Street West), R104, Pelindaba, South Africa; and ${ }^{3}$ Department of Geology, University of Johannesburg, Auckland Park \\ 2006, Johannesburg, South Africa
}

\begin{abstract}
Copper-sulfides within carbonatites and phoscorites of the Phalaborwa Igneous Complex, South Africa, have been investigated since the middle of the $20^{\text {th }}$ Century. However, aspects of ore formation have remained unclear. This study examines the mechanisms involved in $\mathrm{Cu}$-sulfide mineralisation by micro-focus X-ray computed tomography as applied to sulfide-rich drill core samples. Several texturally distinct assemblages of magmatic sulfides can be identified, including: $(1)<500 \mu \mathrm{m}$ rounded bornite and chalcopyrite grains disseminated within the gangue; (2) elongated $\mathrm{mm}$-scale assemblages of chalcopyrite and bornite; and (3) $\mathrm{mm}$-to-cm thick chalcopyrite cumulates. Chalcopyrite veins were also observed, as well as late-stage valleriite, documenting late-stage fluid circulation within the pipe, and alteration of magmatic and hydrothermal sulfides along fractures within the gangue, respectively. The results of micro-focus $\mathrm{X}$-ray computed tomography indicate that magmatic sulfides are sub-vertically aligned. Spatial variability of the sulfide assemblages suggests that textural changes within sulfide layers reflect fluctuating magma flow rate during emplacement of carbonatite-phoscorite magmas, through coalescence or breakup of sulfide liquid droplets during ascent. Modal sulfide abundances, especially for disseminated assemblages, differ from one carbonatite-phoscorite layer to another, suggesting a strong control of the mechanical sorting in the formation of $\mathrm{Cu}$-sulfide textures within the Loolekop carbonatite. The alternation of carbonatite and phoscorite within the intrusion suggest that the Loolekop Pipe was emplaced through a series of successive magma pulses, which differentiated into carbonatite and phoscorite by melt immiscibility/progressive fractional crystallisation and pressure drop. Three-dimensional textural analysis represents an effective tool for the characterisation of magma flow and is useful for the understanding of magmatic processes controlling sulfide liquid-bearing phoscorite-carbonatite magmas.
\end{abstract}

Keywords: carbonatite-phoscorite series, copper sulfides, Phalaborwa Igneous Complex, micro-focus X-ray computed tomography

(Received 31 December 2020; accepted 26 March 2021; Accepted Manuscript published online: 31 March 2021; Associate Editor: David J. Good)

\section{Introduction}

The Loolekop Pipe of the Phalaborwa Igneous Complex is the only known occurrence of a Cu-sulfide deposit of economic interest hosted within a carbonatite-phoscorite intrusion. This deposit has been mined since 1956 by the Palabora Mining Company Ltd., mainly for $\mathrm{Cu}$, but also for other by-products, such as $\mathrm{Fe}$ and U. Copper-sulfide mineralisation within the Loolekop Pipe

\footnotetext{
*Author for correspondence: Loic Y. Le Bras, Email: loic.y.lebras@gmail.com

This paper is part of a thematic set 'Alkaline Rocks' in memory of Dr. Gregory Yu. Ivanyuk

Cite this article: Le Bras L.Y., Bolhar R., Bam L., Guy B.M., Bybee G.M. and Nex P.A.M. (2021) Three-dimensional textural investigation of sulfide mineralisation from the Loolekop carbonatite-phoscorite polyphase intrusion in the Phalaborwa Igneous Complex (South Africa), with implications for ore-forming processes. Mineralogical Magazine 85, 514-531. https://doi.org/10.1180/mgm.2021.32
}

has been studied extensively since the middle of the $20^{\text {th }}$ Century (Lombaard et al., 1964; Hanekom et al., 1965; Groves and Vielreicher, 2001; Giebel et al., 2017). Yet, primary oreforming and late-stage alteration processes have not been entirely characterised (Heinrich et al., 1970; Palabora Mining Company Ltd. Staff, 1976; Vielreicher et al., 2000). Stable-isotope (Fe and $\mathrm{Cu}$ ) and trace-element analysis on $\mathrm{Cu}$-sulfides revealed the presence of a magmatic monosulfide solid solution and intermediate solid solution (mss-iss) system in the Loolekop carbonatitephoscorite intrusion (Le Bras, 2020; Le Bras et al., 2021). However, the mechanisms responsible for magmatic sulfide textures operating during the late stages of magma ascent remain unclear. Previous detailed research was made on the basis of optical and electron microscope observations, as well as electron microprobe analysis of $\mathrm{Cu}$-sulfides on epoxy mounts and thin sections (Rudashevsky et al., 2004; Giebel et al., 2017). Though

(c) The Author(s), 2021. Published by Cambridge University Press on behalf of The Mineralogical Society of Great Britain and Ireland. This is an Open Access article, distributed under the terms of the Creative Commons Attribution-NonCommercial-NoDerivatives licence (http://creativecommons.org/licenses/by-nc-nd/4.0/), which permits non-commercial re-use, distribution, and reproduction in any medium, provided the original work is unaltered and is properly cited. The written permission of Cambridge University Press must be obtained for commercial re-use or in order to create a derivative work. 
such methods provided important constraints on phase compositions, the textural data may not be entirely representative due to stereological bias. Accurate textural analysis of the $\mathrm{Cu}$-sulfide mineralisation within the Loolekop Pipe is critical, considering the spatial variability of mineral associations and textures. Three-dimensional analytical methods are capable of providing a more comprehensive dataset for adequately classifying the Loolekop-hosted $\mathrm{Cu}$-sulfides.

The micro-focus $\mathrm{X}$-ray computed tomography method is made on the basis of density variations between minerals. During X-ray irradiation, dense phases attenuate the beam more than light ones, producing contrast between the different mineral phases in the sample. The measurements generate $2 \mathrm{D}$ attenuation projections (radiographs). The 3D volume employed to interrogate the mineral phases is produced by stacking the $2 \mathrm{D}$ projections. It enables the characterisation of mineral size, distribution, association, internal textural orientation, porosity and mineral modal abundances within the sample. This method is advantageous considering its non-destructive nature, as it consists of the collection of two-dimensional (2D) X-ray projections of a sample followed by image reconstitution to produce a three-dimensional (3D) model. Due to its ability to examine these parameters, micro-focus X-ray computed tomography (microCT) has been used successfully to describe various types of mineralisation (Barnes et al., 2008; Godel et al., 2010; Cnudde and Boone, 2013; Barnes et al., 2019). This analytical method is particularly useful in deciphering textural relationships between ore minerals, and consequently identifying ore-forming processes (Godel et al., 2010, 2013).

Copper-sulfide mineralisation in the Loolekop Pipe is particularly complex. The spatial variability and the number of sulfide phases make the identification of mineral paragenesis challenging. Three-dimensional microCT analysis of drill core pieces from different rock types of the intrusion provide comprehensive and representative information regarding the distribution, shape and mineral associations of the $\mathrm{Cu}$-sulfide mineralisation, including spatial relationships between the different $\mathrm{Cu}$-bearing phases. The use of this method for the characterisation of $\mathrm{Cu}$-sulfides from the Loolekop Pipe of the Phalaborwa Igneous Complex represents a novel approach to understand the metallogenesis of this unusual deposit.

\section{Geological setting}

\section{The Phalaborwa Igneous Complex}

The Phalaborwa Igneous Complex is located in Limpopo Province, South Africa, $\sim 450 \mathrm{~km}$ northeast of the city of Johannesburg. The complex is the outcome of successive intrusions of several magma pulses into the granitoid-gneiss basement of the Archaean Kaapvaal Craton. The igneous complex is composed of three distinct intrusive centres producing three adjacent lobes aligned on a North-South axis forming an $18.5 \mathrm{~km}^{2}$ ellipsoid (Fig. 1a). The complex is characterised by mafic rocks along the external boundaries of the complex, and carbonatitic rocks towards its core. The first magma pulse emplaced a feldspathic pyroxenite unit forming an aureole around the intrusive complex along the contact with the basement. It has been shown that the presence of feldspars is not related to any interaction with the gneissic-granitic host rock (Eriksson, 1982). Fenitisation of the Kaapvaal host rocks can be observed along the contact with the feldspathic pyroxenite. Post-dating the feldspathic pyroxenite, a second magma pulse crystallised a micaceous pyroxenite, which constitutes a major part of the igneous intrusion (Fig. 1a). This rock is composed of phlogopite, diopside and apatite (Heinrich, 1970; Eriksson, 1982). The phlogopite content varies within the intrusion. Mineral assemblage alignments indicate the presence of magmatic flow during emplacement of these rocks. Weathering of the micaceous pyroxenite has resulted in the alteration of phlogopite to vermiculite (Palabora Mining Company Ltd. Staff, 1976). Thereafter, pyroxene pegmatites were emplaced as three intrusive centres, each being characterised by distinct modal compositions. The southern pegmatite is composed of diopside and phlogopite with minor fluorapatite and serpentine (Eriksson, 1982). The northern pegmatite consists of a ring-shaped phlogopite-, diopside- and apatite-bearing unit surrounding a rock composed of diopside, serpentine and phlogopite. The central pegmatite consists of phlogopite, diopside and apatite. Syenite magma intruded into gneisses and granites of the Kaapvaal Craton to form syenite plugs all around the complex. Late gabbro dykes cross-cut all country rocks and the complex along a northeast-southwest axis.

\section{Geological characteristics of the Loolekop Pipe}

The central intrusion, henceforth named Loolekop Pipe, represents a sub-vertical body, which was emplaced at the intersection of five major faults and shear zones (Basson et al., 2017). The first rocks to crystallise were phoscorite at the outer parts of the Loolekop Pipe and banded carbonatite to the centre of the intrusion (Fig. 1b). Both banded carbonatite and phoscorite are marked by the presence of planar mineral alignments. Alternate vertical layers of banded carbonatite and phoscorite form a progressive transition from massive phoscorite at the external boundaries of the Loolekop Pipe to banded carbonatite towards the core (Fig. 1c). A later structural event imparted a dense stockwork in the core of the pipe and reactivated igneous activity, allowing the emplacement of a second carbonatite magma pulse, forming the transgressive carbonatite, into the fracture network in the centre of the intrusion (Lombaard et al., 1964; Heinrich, 1970).

The phoscorite in the Loolekop Pipe is a coarse-grained rock $(5 \mathrm{~mm}$ to $6 \mathrm{~cm}$ ) composed mainly of magnetite and apatite with lesser extents of diopside and phlogopite in a calcite matrix (Eriksson, 1982). The banded carbonatite unit consists mainly of medium- to coarse-grained $(1 \mathrm{~mm}$ to $2 \mathrm{~cm}$ ) calcite and dolomite with minor amounts of magnetite, apatite and diopside. Both banded carbonatite and phoscorite show magnetite-, apatiteand silicate-bearing planar alignments, forming sub-vertical cumulates in the intrusive pipe (Lombaard et al., 1964; Hanekom et al., 1965; Palabora Mining Company Ltd. Staff, 1976). The transgressive carbonatite is composed of coarsegrained $(5 \mathrm{~mm}$ to $5 \mathrm{~cm}$ ) calcite and dolomite with traces of apatite, magnetite and diopside, which are all apparently related to the replacement of banded carbonatite/phoscorite during magma ascent.

The timing of emplacement of the Loolekop Pipe has been investigated using various analytical techniques. Uranium- $\mathrm{Pb}$ thermal ionisation mass spectrometry (TIMS) analysis of baddeleyite produced ages of $2059.8 \pm 0.8 \mathrm{Ma}$ and $2060.6 \pm 0.5 \mathrm{Ma}$ (Heaman and LeCheminant, 1993; Reischmann, 1995). Secondary ion mass spectrometry (SIMS) U-Pb analysis on zircons from the pyroxene-bearing pegmatite, phoscorite, banded carbonatite and transgressive carbonatite produced ages estimated at $2060 \pm 4 \mathrm{Ma}, 2060 \pm 1 \mathrm{Ma}, 2060 \pm 2 \mathrm{Ma}$ and $2060 \pm 1 \mathrm{Ma}$, respectively ( $\mathrm{Wu}$ et al., 2011). These ages suggest a synchronous emplacement of the main geological units. Compositions of banded carbonatite and phoscorite indicate a cogenetic origin of 


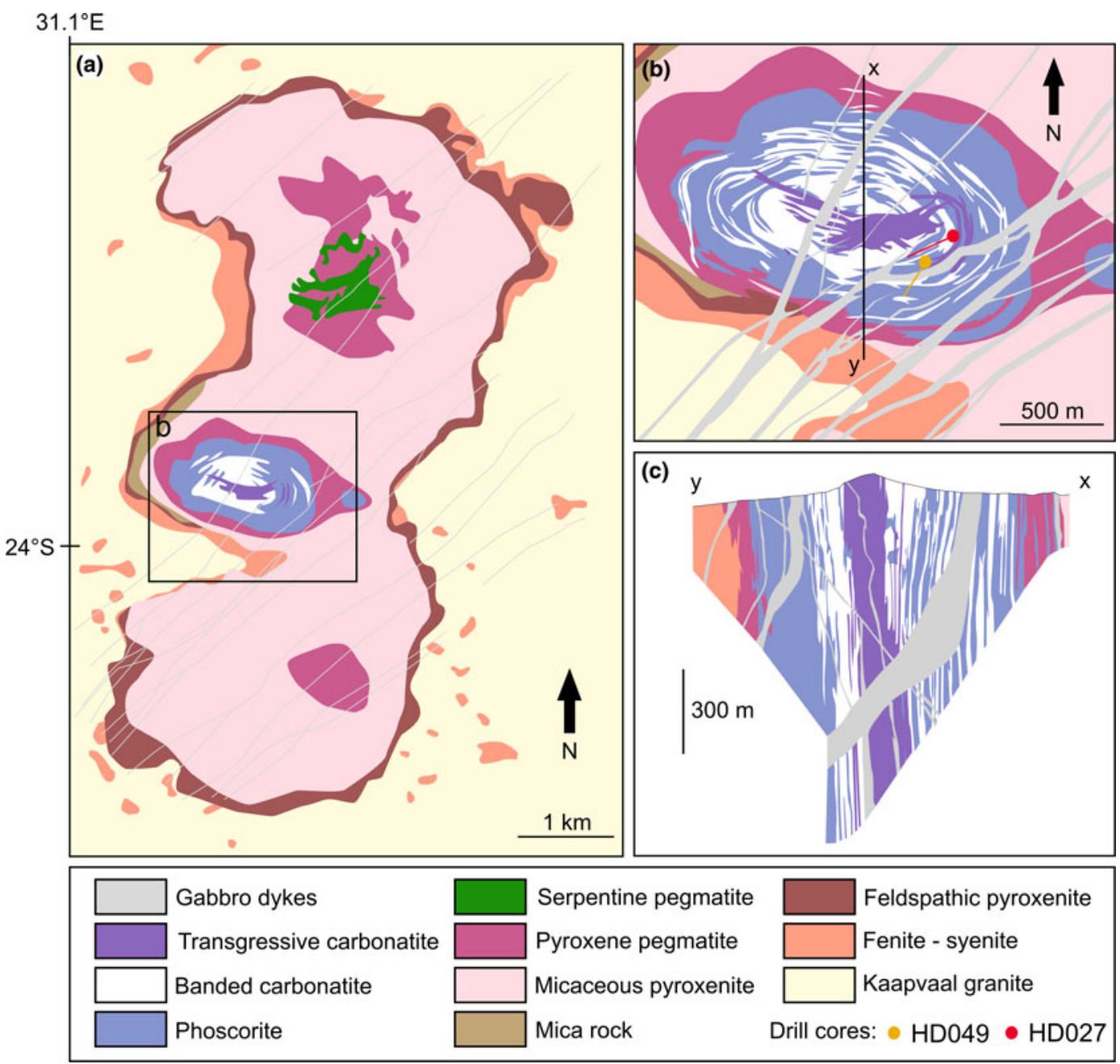

Fig. 1. (a) Simplified geological map of the Phalaborwa Igneous Complex. (b) Enlarged view of the Loolekop Pipe with surface projections of the drill core collars and orientations. The drill cores have a sub-horizontal orientation. (c) Vertical cross-section defined by the $x-y$ line on (b). Modified after Palabora Mining Company Ltd. Staff (1976) and Le Bras et al. (2021).

these two rocks, which support the concept of a rapid emplacement of the Loolekop carbonatite-phoscorite complex (Wu et al., 2011; Milani et al., 2017a, b).

\section{Copper sulfides in the Loolekop Pipe}

Chalcopyrite represents the dominant sulfide in terms of volume within the Loolekop Pipe (Palabora Mining Company Ltd. Staff, 1976). It occurs as two different types defined by specific mineral associations and textures. The first type constitutes the largest part of the sulfide mineralisation within the Loolekop Pipe and is characterised by networks of sub-vertical veinlets occurring in wide zones (up to several $\mathrm{m}$ ) along fractures within the transgressive carbonatite (Palabora Mining Company Ltd. Staff, 1976; Vielreicher et al., 2000). Chalcopyrite, as part of this mineralisation, is commonly associated with cubanite, the latter being present either as exsolution lamellae or grains (Lombaard et al., 1964; Palabora Mining Company Ltd. Staff, 1976; Le Bras et al., 2021). The second type occurs as disseminated grains (50 to $500 \mu \mathrm{m})$ associated with small modal amounts of bornite within banded carbonatite and phoscorite, and is present in minor amounts relative to chalcopyrite (Palabora Mining Company
Ltd. Staff, 1976). Disseminated grains of chalcopyrite have also been observed within the micaceous pyroxenite.

Bornite has been reported as the second most important sulfide in terms of abundance in the Loolekop Pipe and represents the dominant phase within the banded carbonatite and phoscorite. This mineral is associated with disseminated chalcopyrite in banded carbonatite and phoscorite, but also occurs as an isolated phase. Both bornite and chalcopyrite can be found disseminated within the carbonate gangue, though they are also associated with magnetite and apatite cumulates. Intergrowths of chalcocite and bornite have also been observed.

Late-stage valleriite occurs together with primary sulfides along cracks and edges of chalcopyrite and bornite (Le Bras et al., 2021). Various trace sulfides have also been reported in the Loolekop rocks, such as pentlandite, millerite, bravoite, tetrahedrite, sphalerite, pyrite and galena, as well as platinum-group minerals (Bulakh et al., 1998; Rudashevsky et al., 2004).

Trace-element analyses of sulfide assemblages reveal an enrichment of Pd (average of $91 \mathrm{ppb}$ ) over $\mathrm{Pt}$ and other platinum-group elements (PGE) in the Ir-group (IPGE: Os, Ir, $\mathrm{Ru}$; up to $20 \mathrm{ppb}$ ), consistent with the operation of a mss-iss system in the Loolekop Pipe (Le Bras et al., 2021). This originates from a magmatic process, characterised by the formation of two 
phases from the sulfide liquid during magma ascent. The first consisted of an Fe- and IPGE-rich sulfide cumulate (mss) and the second of a Cu- and Pd-group PGE (PPGE: Pd, Pt)-rich sulfide liquid, which later precipitated an iss. The iss further evolved in $\mathrm{Cu}$-sulfide assemblages during cooling. The depletion in $\mathrm{Pt}$ of sulfide phases is regarded as the consequence of the formation of sperrylite $\left(\mathrm{PtAs}_{2}\right)$ during the magmatic stage.

\section{Samples and methods}

\section{Samples}

Forty five pieces of drill core from two boreholes were selected from the Palabora Mining Company drill-core collection. Samples consist of drill-core quarters with a $1.75 \mathrm{~cm}$ radius. Sampled cores were drilled sub-horizontally at the second lift level of the mine, $\sim 1250 \mathrm{~m}$ below surface. Twelve samples from different rock types were chosen for microCT analysis on the basis of their $\mathrm{Cu}$-sulfide content to ensure optimal characterisation of the mineralisation (Supplementary material - Appendix 1). A polished epoxy mount was prepared from one of the drill core samples in order to identify the different ore phases in the tomographic images.

\section{Micro-focus X-ray computed tomography}

Analyses were performed at the Micro-focus X-ray Radiography and Tomography (MIXRAD) facility at the South African Nuclear Energy Corporation (NESCA) at Pelindaba in South Africa.

The procedure to acquire the data consists of four steps. The first consists of the acquisition of the $2 \mathrm{D}$ image projections (2000 projections) of the drill-core samples through a $360^{\circ}$ rotation. A Nikon XTH 225 CT system with a multi-target source $(\mathrm{Mo}, \mathrm{Cu}, \mathrm{Ag}, \mathrm{W})$ was used to acquire the $2 \mathrm{D}$ projections. The instrument has been described in detail elsewhere (Hoffman and De Beer, 2012). The drill-core samples were mounted in a Plexiglas ${ }^{\circledast}$ cylinder and held in place by polystyrene pieces to avoid any movement of the samples during scanning. The scanning resolution was set between 28 and $45 \mu \mathrm{m}^{3}$ (voxel size) depending on the sample size. To optimise the image contrast, the exposure time was set to $4 \mathrm{~s}$ and the source voltage to $100 \mathrm{kV}$. A $0.5 \mathrm{~mm} \mathrm{Cu}$ filter was used to minimise the impact of beam hardening and to improve X-ray penetration. A 16-bit dynamic range Perkin Elmer flat-panel detector was employed to capture the projections. This detector has an effective size of $400 \mathrm{~mm} \times 400 \mathrm{~mm}$ and a pixel size of $200 \mu \mathrm{m} \times 200 \mu \mathrm{m}$.

The second step involves the reconstruction of the $2 \mathrm{D}$ image projections into a $3 \mathrm{D}$ volume using the $\mathrm{CT}$ Pro $3 \mathrm{D}$ software. A beam hardening correction of 2 was used to further minimise the impact of beam hardening and optimise image contrast. In this case, the reconstructed $3 \mathrm{D}$ volume comprises the $2 \mathrm{D}$ image slices.

This step was followed by pre-processing of the 2D image slices using ImageJ free software (Schneider, 2012). A certain grey value related to the low-density phases (gangue minerals) is subtracted to improve the overall contrast between the dense phases (Fig. 2). The segmentation was done using the built-in segmentation grey value range function of the VG Studio Max software version 3.2 (Volume Graphics $\mathrm{GmbH}$ ). This function allows a certain grey value range (attributed to the minerals) to be isolated from the entire sample. The attenuation coefficient information illustrates that the discrimination between minerals of interest (magnetite, chalcopyrite, bornite, valleriite) is possible (Fig. 3). It is particularly the case between chalcopyrite and magnetite in the Loolekop Pipe due to the high Ti content of magnetite (Milani et al., 2017a), which significantly lowers its attenuation coefficient (Fig. 3). The porosity of magnetite associated with chalcopyrite is also a factor leading to a lower attenuation factor (Fig. 2b).

The final step consists of restoring a 3D volume of the phase of interest from the stacking of segmented 2D image slices using the VG Studio Max software version 3.2 (Fig. 4). For better visualisation, a false colour was assigned to each phase of interest to indicate occurrence and distribution within the drill cores.

\section{Mineral liberation analysis}

Mineral liberation analysis (MLA) was carried out on a sulfide-rich sample mounted in epoxy resin to obtain a detailed overview of both sulfide phases and textures, and to optimise tomographic data processing. The polished mount was prepared from a drill-core piece previously analysed by micro-focus X-ray computed tomography.

The MLA was performed using a FEI Quanta 600 FEG MLA with two Bruker Xflash X-ray detectors at the University of Johannesburg. Analyses were conducted at a working distance of $13 \mathrm{~mm}$. The acceleration voltage was set at $25 \mathrm{kV}$ and the current at the surface of the specimen at $10 \mathrm{nA}$. X-ray detectors were calibrated against a $\mathrm{Cu}$ standard. Calibration of the back-scattered electron (BSE) grey level was performed against $\mathrm{Au}, \mathrm{Cu}$ and quartz standards. Sulfide and gangue phases collection times were set at $10 \mathrm{~ms}$ and $30 \mathrm{~ms}$, respectively. Mineral maps were created using the GXMAP measurement mode, which performs $\mathrm{X}$-ray analysis according to a grid format with a point spacing set at $13 \mu \mathrm{m}$.

\section{Results \\ MicroCT spatial resolution}

The MLA results permit the accurate identification and textures of sulfides of interest, and also enables the assignment of microCT grey level intervals to the different phases (Figs 2 and 4). Mineral Liberation Analysis also revealed the limited spatial resolution of the microCT where the structural features are smaller than the resolution, affecting the contrast. Small-scale mineralisation features $(\sim 10 \mu \mathrm{m})$ visible on the BSE image and MLA mineral map (Fig. 2a,b) cannot be distinguished on the corresponding $2 \mathrm{D}$ linear attenuation projection (Fig. $2 \mathrm{c}$ ). Therefore, only the major features of the sulfide mineralisation were observed and interpreted with microCT analysis.

\section{Ore mineralogy}

Combined microscopic observations and microCT analysis reveals three distinct categories of sulfide mineralisation: (1) gangue-hosted disseminated Cu-sulfides; (2) chalcopyrite veins; and (3) secondary sulfides associated with the two first categories (Figs 5 to 11 and Table 1).

\section{Microscopic observations}

Copper sulfides disseminated within the gangue typically exhibit fine-grained (up to $500 \mu \mathrm{m}$ ) chalcopyrite and bornite assemblages 
Fig. 2. (a) Electron microscope image of a sulfide-rich slice. (b) High-resolution Mineral Liberation Analysis mineral map corresponding to a part of the picture in (a). (c) Raw microCT 2D projection of sulfide phases (medium grey) in a carbonatite matrix from sample 17 (Appendix 2). (d) Processed 2D projection slice with high contrast between the ore phases and the gangue.

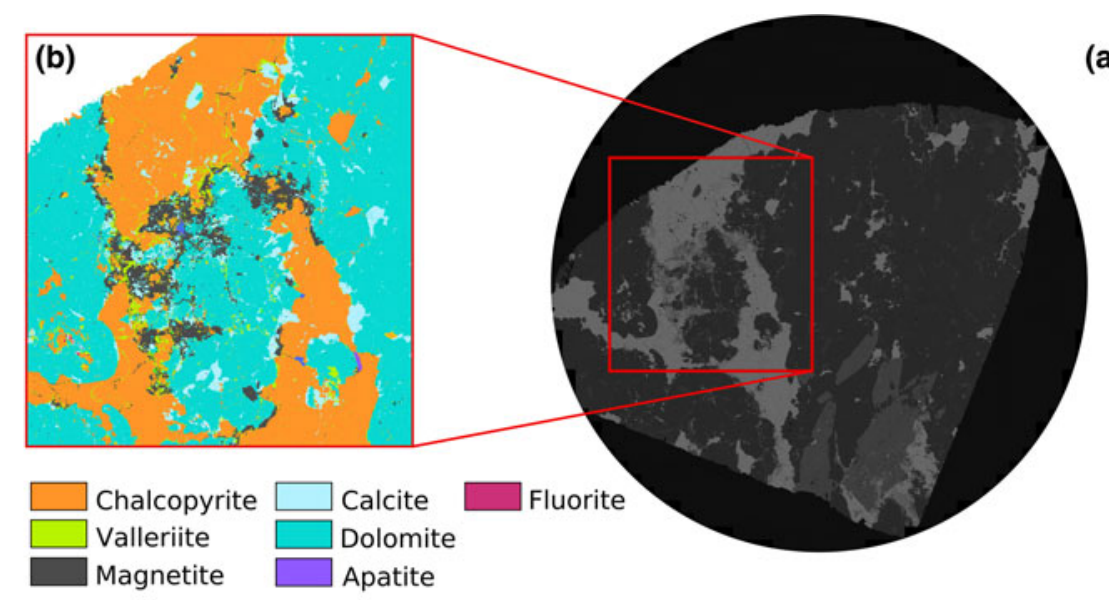

(a)
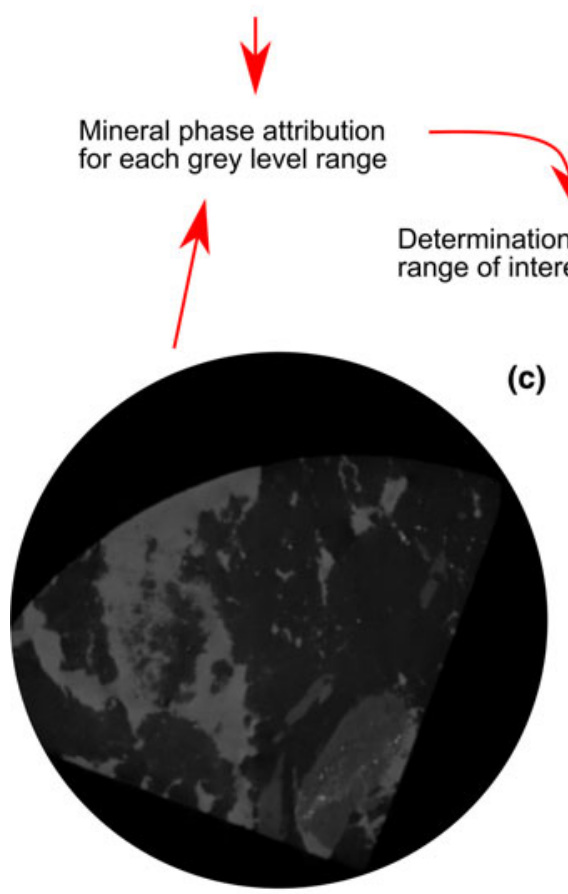

within banded carbonatite and phoscorite (Figs 5a-e). Chalcopyrite is also present as small interstitial veinlets $(\sim 20$ $\mu \mathrm{m}$ wide, $\sim 400 \mu \mathrm{m}$ long) connected to disseminated grains (Fig. 5c). Bornite grains $(\sim 200-300 \mu \mathrm{m})$ are observed in association with chalcopyrite and, occasionally, with magnetite (Fig. 5a,b,e). Locally, intricate bornite-chalcocite assemblages can be observed (Fig. 5e). Within bornite grains, chalcopyrite is mainly present as exsolution or replacement lamellae and patches (Fig. 5a,b). As shown in Fig. 5f, chalcopyrite can also form greater than $1 \mathrm{~mm}$-wide veins with cubanite exsolution lamellae. Valleriite alteration can be observed in cracks and veins in the gangue, but also along the rims of the sulfide assemblages themselves. Valleriite is commonly very fine-grained and unevenly distributed within the Loolekop Pipe (Fig. 5b,d,e).

\section{MicroCT}

Three-dimensional modelling of sulfide mineralisation reveals several types of textures that are not obvious from conventional petrographic examination due to the limited number of polished mounts examined of $\mathrm{Cu}$-sulfides in the Loolekop Pipe. The three main textural types are: (1) disseminated grains (Figs 6 to 9); (2) flat and elongated assemblages (Figs 7 and 8); and (3) sulfide cumulates (Figs 6 to 9). Disseminated sulfides are present in all of the samples. These typically show alignments (Figs 9 and 10), which can be difficult to identify in samples with high grain density. Elongated assemblages are up to several $\mathrm{mm}$ long (Figs 7a,b; 8a,b). This textural type is dominated by chalcopyrite. Three-dimensional tomographic analysis can show lengths greater than $10 \mathrm{~mm}$ in some cases, but observations are limited by the 


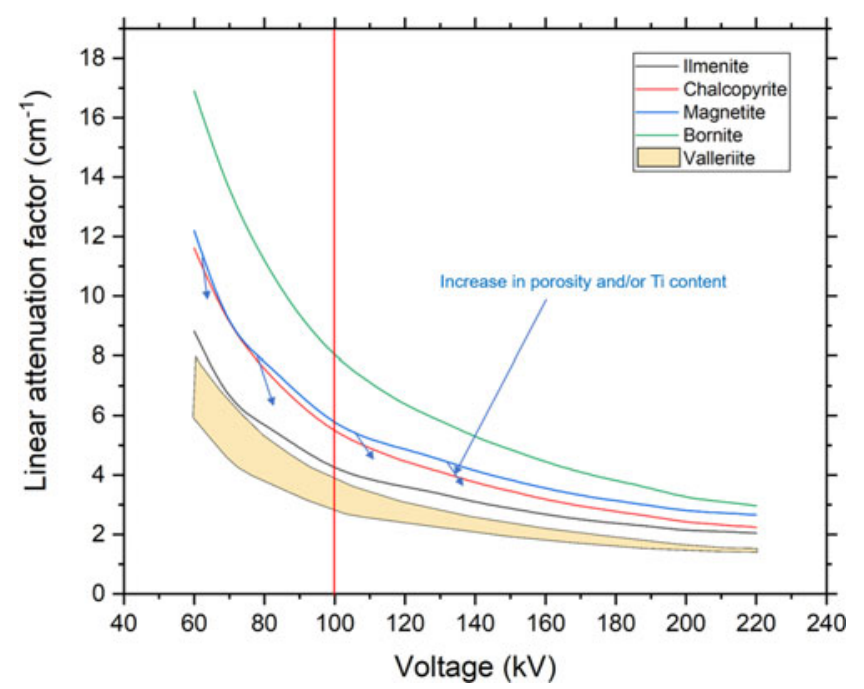

Fig. 3. Graph showing calculated theoretical linear attenuation coefficients for ore minerals within the Loolekop Pipe depending on the voltage of the X-ray source. The wide variation for valleriite is due to the complex and variable composition of this mineral. The difference between chalcopyrite and magnetite attenuation factors increases with an increase of source voltage.

diameter of the drill core. The thickness of elongated assemblages rarely exceeds $\sim 3 \mathrm{~mm}$. Sulfide cumulates are present as layers in the host rock (Figs 6 to 9). The cumulate thickness is highly variable and ranges from $1 \mathrm{~mm}$ (Fig. 9) to $>1.5 \mathrm{~cm}$ (Fig. 8). These cumulates display a planar orientation, trending subperpendicular to the drill-core axis.

Another textural category is characterised by chalcopyrite veins (Fig. 11) showing a sharp contact with the host rock. The vein width reaches $\sim 1 \mathrm{~cm}$ in this investigation (Fig. 11). Oriented sulfide assemblages are present adjacent to the vein. No fractures were observed between these alignments and the vein itself.
MicroCT analysis also reveals the presence of late-stage valleriite associated with chalcopyrite and bornite (Figs 9 and 10). However, its distribution among the samples is heterogeneous: some samples are valleriite-free (Figs 6 and 8), whereas others host a significant amount of this mineral (Figs 9 and 10). MicroCT analysis documents the association of valleriite with all types of chalcopyrite and bornite mineralisation categories (disseminated, elongated assemblages and cumulates), except with chalcopyrite veins (Fig. 11).

Overall, sulfide grain sphericity is dependent on sulfide diameter: it increases with decreasing grain size. The sphericity of sulfides in the Loolekop Pipe ranges from 0.7 to 0.2 , but can reach 0.05 in some samples (Figs $8 c, 9 c$ and 10c). A sphericity of less than 0.15 is typical of sulfide cumulates and corresponds to a sulfide diameter greater than $8 \mathrm{~mm}$. Typically, a sphericity of 0.5 is for grain diameters of 0.1 to $1 \mathrm{~mm}$. Sphericity increases to 0.7 for sulfides with a diameter of 0.1 to $0.3 \mathrm{~mm}$.

Sulfide assemblage sizes are not entirely dependent on the sulfide type. However, the results show that disseminated sulfides occupy small volumes (typically up to $50 \mathrm{~mm}^{3}$; with some samples up to $100 \mathrm{~mm}^{3}$ ) whereas elongated assemblages typically range from 75 to $600 \mathrm{~mm}^{3}$. It can be difficult to distinguish elongated sulfides from cumulates as the volumes of these two types overlap.

\section{Planar sulfide layers}

Disseminated sulfides (Figs 9 and 10), as well as elongated sulfides (Fig. 8) and cumulates (Figs 7 to 9) display planar layers within the banded carbonatite and phoscorite. Layers of sulfides with particular textures might be in contact with layers of another type (Figs $7 \mathrm{~b}, 8 \mathrm{~b}, 9 \mathrm{~b}$ and $10 \mathrm{~b}$ ). A common feature of the sulfides is the alternating array of several layered textures. Macroscopic banding is formed from the alternation between disseminated sulfide layers and flat elongated chalcopyrite-bornite assemblages, as well as sulfide cumulates.

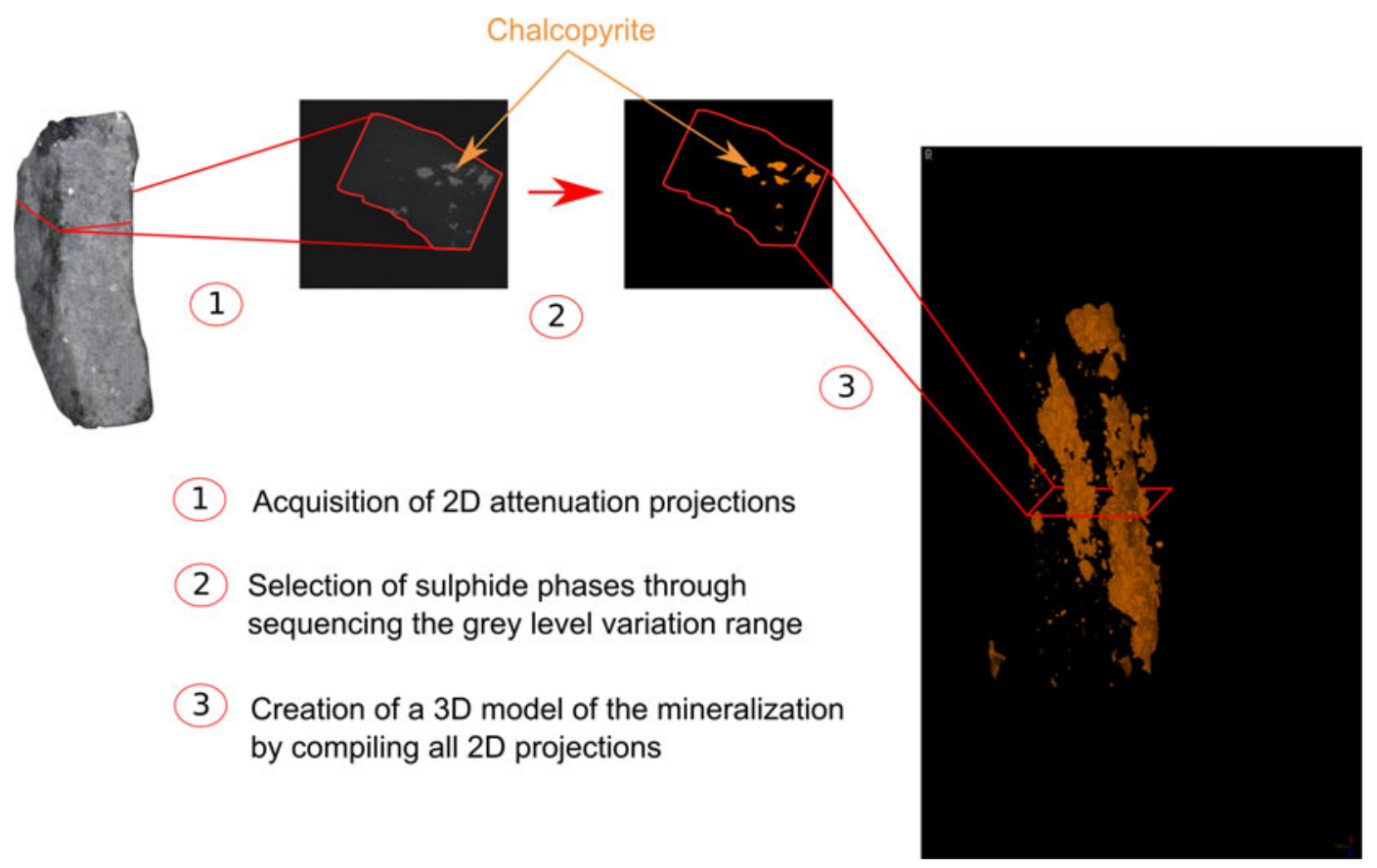

Fig. 4. Graphic illustration of the method applied for data processing, from data acquisition to the 3D model creation. 

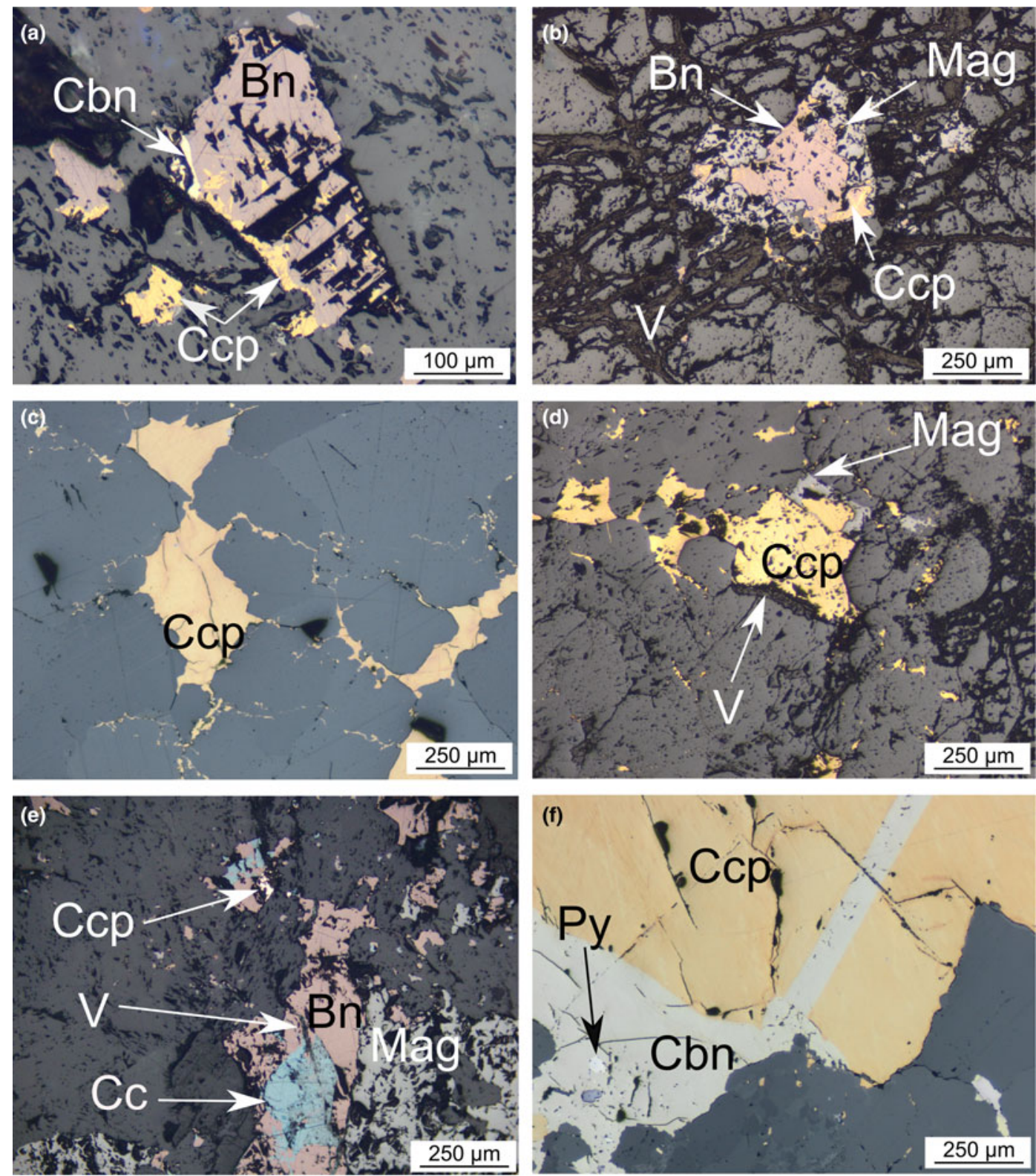

Fig. 5. Photomicrographs of the different sulfide assemblages observed in the Loolekop Pipe. $\mathrm{Bn}=\mathrm{bornite}, \mathrm{Cbn}=\mathrm{cubanite}, \mathrm{Cc}=\mathrm{chalcocite}, \mathrm{C} \mathrm{cp}=\mathrm{chal} \mathrm{copyrite}$, Mag = magnetite and V = valleriite. (a) Bornite grain associated with chalcopyrite and cubanite disseminated in the gangue. (b) Similar grain as in (a) with fracture network filled by valleriite and magnetite association. (c) and (d) Disseminated chalcopyrite grains within the gangue accompanied by interstitial chalcopyrite between adjacent gangue minerals. (e) Intricate bornite-chalcocite assemblage associated with magnetite. (f) Vein-hosted chalcopyrite-valleriite assemblage associated with fine-grained pyrite.

The orientation of the sulfide layers is sub-perpendicular to the drill-core axis in the samples studied (Figs 7 to 9). Hence, the subhorizontal dip of drill-core samples suggests that layers are subvertical and parallel to the phoscorite-banded carbonatite layers and to the external edges of the Loolekop Pipe (Appendix 1).

\section{Discussion}

\section{Textures and origin of magmatic sulfide mineralisation}

Characterisation of sulfide textures permits the recognition of different categories of mineralisation (Figs 5 to 11, Table 1). The first sulfide category, consisting of $\mathrm{Cu}$-sulfide layers, is present in both banded carbonatite and phoscorite. As indicated by microCT results, fine-grained sulfides $(<500 \mu \mathrm{m})$ are disseminated in their host rock with no association with structural features, suggesting a synchronous emplacement with carbonates, Fe-oxides and silicates (Fig. $5 \mathrm{a}-\mathrm{e}$ ). These sulfides are probably of magmatic origin due to their inclusion in the host rock. This is in agreement with the model developed by Le Bras et al. (2021), which suggests the occurrence of a mss-iss system within the Loolekop Pipe, with the fractionation of an ascending $\mathrm{Cu}$-rich sulfide liquid from a mss remaining at depth, followed by the formation of an iss and the further crystallisation of bornite and chalcopyrite assemblages during the emplacement of the phoscorite and banded carbonatite. This assumption is supported by the PGE contents and the radiogenic $\mathrm{Pb}$ isotope composition of sulfide phases, reflecting a mantle 

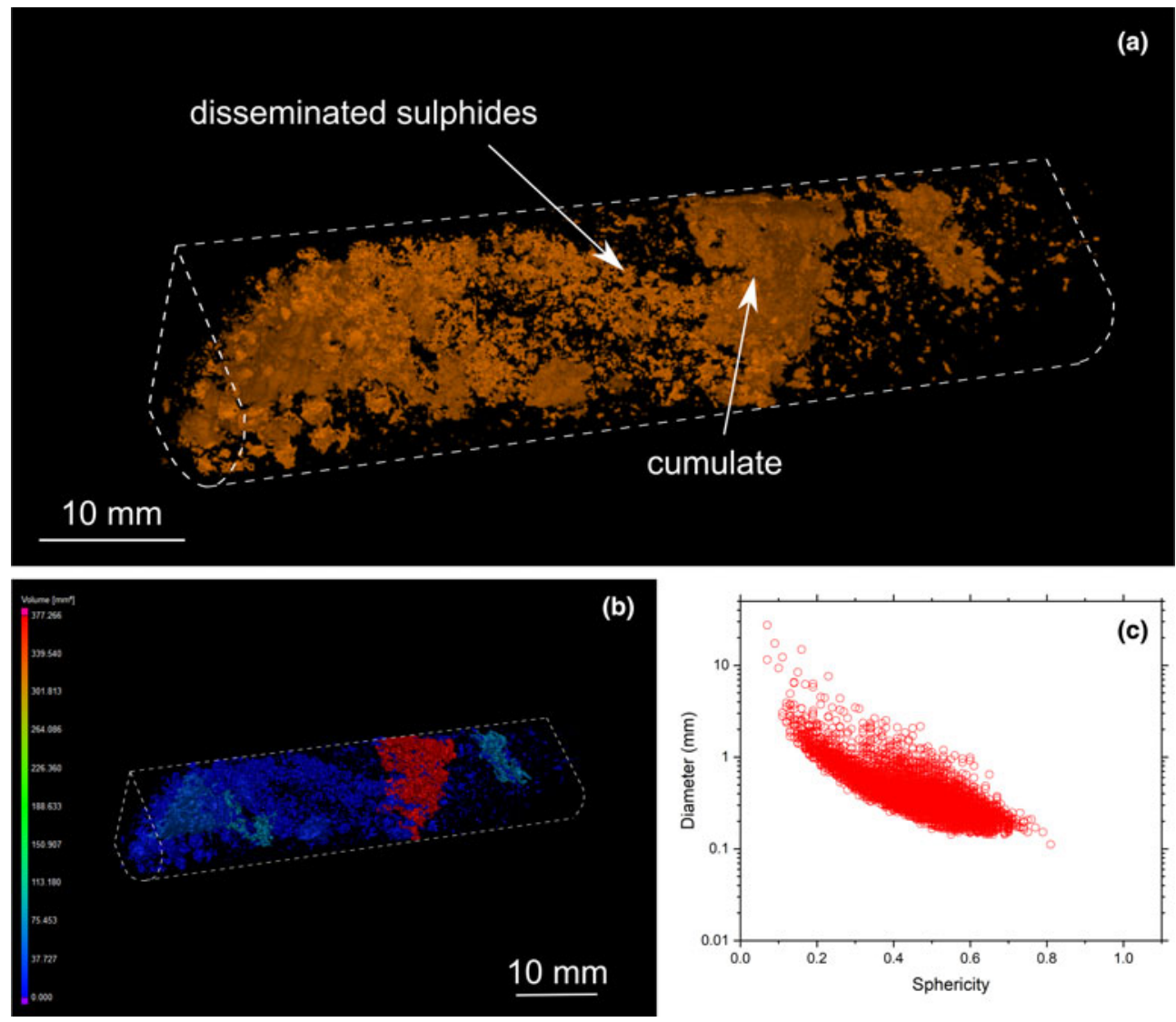

Fig. 6. (a) Three-dimensional volume rendering of drill-core sample 56 (banded carbonatite) with chalcopyrite (orange) and valleriite (green). (b) Three-dimensional heatmap for chalcopyrite phases. Red, green and blue correspond to large, medium and small volumes, respectively. (c) Graph plotting the diameter of chalcopyrite versus sphericity.

origin of the ore material (Bolhar et al., 2020; Le Bras et al., 2021). Moreover, an enrichment of PPGE over IPGE in disseminated sulfides is an indication of mss fractionation, therefore supporting the hypothesis of a magmatic origin of these ore phases. In $\mathrm{mm}$ - to $\mathrm{cm}$-long elongated assemblages, bornite is mainly present inside the aggregates (e.g. Appendix 2, sample 22), making its recognition within the $3 \mathrm{D}$ model challenging. The relationship between bornite and chalcopyrite can only be assessed effectively by sequential observation of $2 \mathrm{D}$ attenuation projections or by optical microscopy (Figs 5a-b; Appendix 2). The lower resolution of microCT compared to electron microscope imagery does not permit the recognition of chalcopyrite exsolution or replacement in bornite, as well as other micrometre-scale textural features (Fig. 2; Hoffman and De Beer, 2012), suggesting that MLA mineral mapping should be used systematically for detailed textural investigations on sulfides having similar X-ray attenuation coefficients.

Sulfides are present as sub-vertical layers parallel to phoscorite and banded carbonatite layers (Figs 1, and 6 to 10; Appendices 1 and 2), suggesting that the controlling process for sulfide layering might be the same as for the banded carbonatite and phoscorite. A clear example of alternating gangue and sulfide banding can be observed in Fig. 9. Sulfide layer textures show no homogeneous characteristics, consistent with operation of several independent but similar ore-forming events (Mao et al. 2008).

MicroCT results show a clear dominance of chalcopyrite over bornite in disseminated sulfides (Figs 7b,d and 9b,d), which contrasts with previous studies. Microscopic observations rather indicate a bornite-dominated mineralisation suggesting a heterogeneous distribution of mineral assemblage types throughout the intrusive body (Le Bras et al., 2021). The presence of elongated sulfide assemblages with diameters of $\sim 1 \mathrm{~mm}$ implies coalescence between sulfide droplets (Lesher and Groves, 1986; Robertson et al., 2015). High-energy magma flow does not produce coalescence but rather the breakup of droplets with diameters greater than $1 \mathrm{~mm}$ (Lesher and Groves, 1986; de Bremond d'Ars, 2001). The planar orientation of elongated sulfides suggests a laminar flow, parallel to the banded carbonatite-phoscorite alternation layers (Robertson et al., 2015). Massive sulfide cumulate layers are present within the Loolekop Pipe (Figs 7 to 10) pointing to accumulation of sulfide liquid resulting from the mechanical sorting and segregation of sulfide liquid from the silicate melt (Zeig and Marsh, 2005; Vukmanovic et al., 2018). These cumulates form exclusively during fast segregation. In such cases, sulfide liquid and silicate melt separate and the sulfide liquid forms a sulfide layer (Zeig and Marsh, 2005). The presence of several layers of sulfides of different textures points towards an emplacement of several magma pulses with variable flow rates.

The relative proportions of bornite and chalcopyrite show substantial variation between the different sulfide layers (Appendix 2), suggesting a strong control of the mineral density in the formation of the different alignments. Considering spatially variable bornite-chalcopyrite modal proportions, it is possible that these sulfides were affected by mechanical sorting produced by rotating magma flow at variable rates during the ascent which contributed to the formation of the different types of 

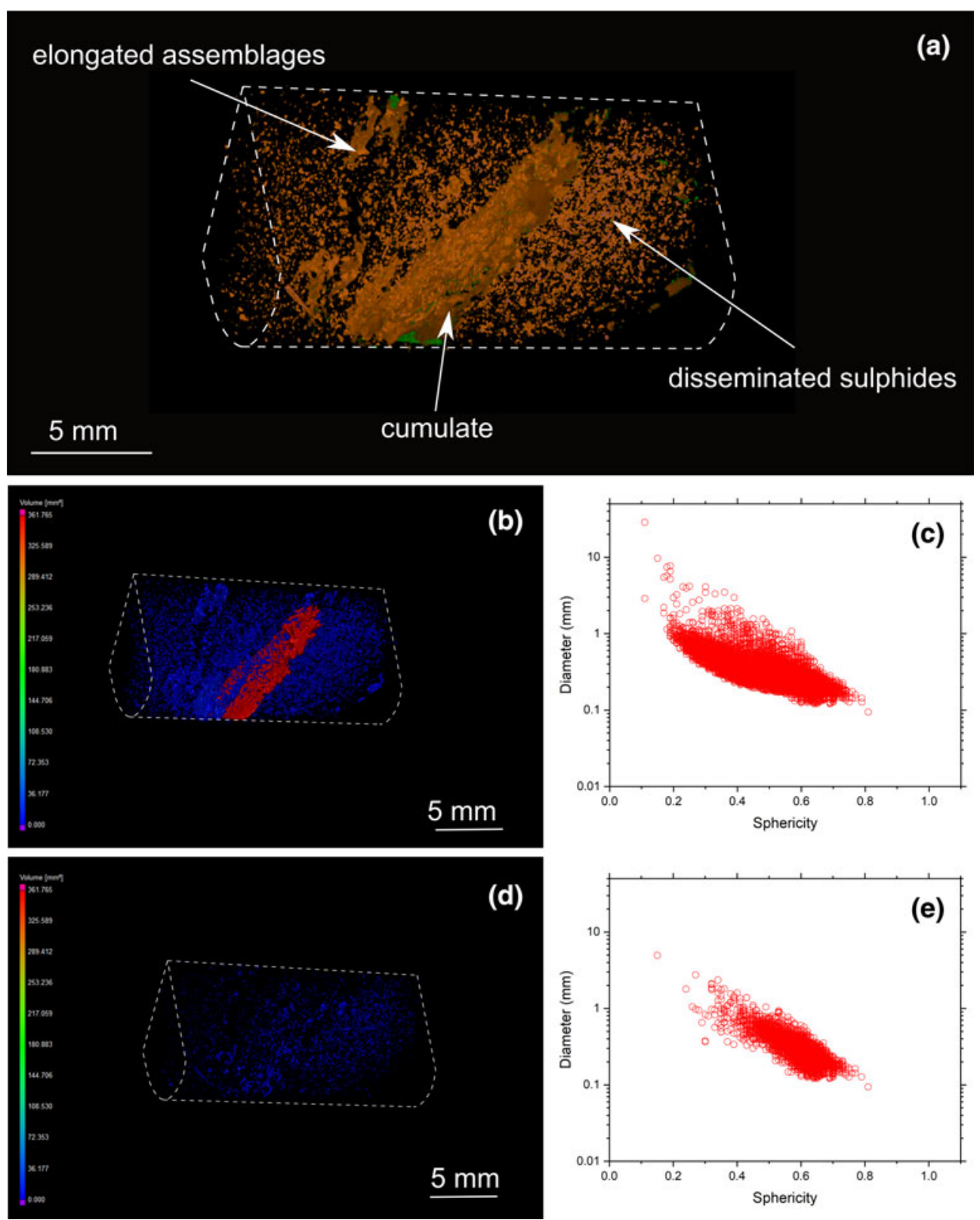

Fig. 7. (a) Three-dimensional volume rendering of drill-core sample 22 (banded carbonatite) with chalcopyrite (orange) and valleriite (green). (b) Three-dimensional heatmap for chalcopyrite phases. Red, green and blue correspond to large, medium and small volumes, respectively. (c) Graph plotting the diameter of chalcopyrite against sphericity. (d) Three-dimensional heatmap for bornite phases (e) Graph plotting the diameter of bornite against their sphericity.

sulfide assemblages during emplacement of the banded carbonatite and phoscorite and cooling of the system (Cabri, 1973). Trace-element compositions of magmatic sulfides are similar between banded carbonatite and phoscorite samples, regardless of some slight discrepancies for $\mathrm{Co}, \mathrm{Pb}$ and $\mathrm{Bi}$ (Fig. 12 and Table 2). This is best explained by the homogenisation of the sulfide liquid during the ascent.

\section{Banded carbonatite and phoscorite emplacement process}

The presence of sub-vertical carbonatite-phoscorite banding and sulfide layers indicates the successive emplacement of different magma pulses in the Loolekop Pipe (Figs 13 and 14). These pulses show a progressive decrease in Fe-oxide, apatite and silicate contents from early- to late-stages of the intrusion process as suggested by the preferential emplacement of banded carbonatite towards the centre and phoscorite at the edge of the pipe. This feature furthermore suggests a cogenetic origin for the two rock types and control of immiscibility between their parent melts, similar to other occurrences of carbonatite-phoscorite intrusions (Brod et al., 2013). Textural and compositional uniformity of fluorapatite and calcite supports a cogenetic emplacement of both carbonatite and phoscorite in the Loolekop Pipe (Milani et al., 2017b). On the basis of the composition of apatite and mica, Giebel et al. (2019) also advocated a common origin for these two rocks. In the Loolekop Pipe, immiscibility combined 

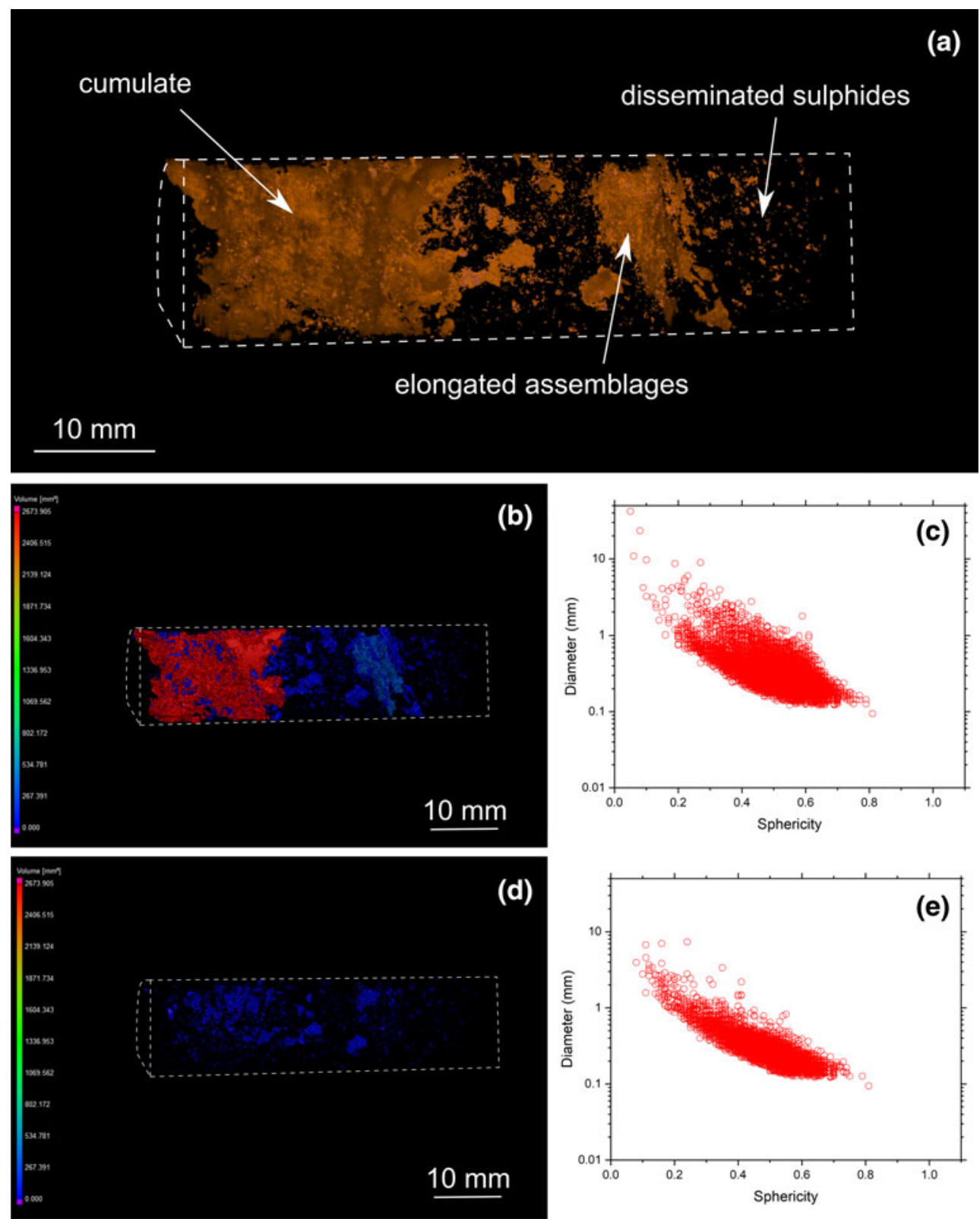

Fig. 8. (a) Three-dimensional volume rendering of drill-core sample 58 (banded carbonatite) with chalcopyrite (orange) and valleriite (green). (b) Three-dimensional heatmap for chalcopyrite phases. Red, green and blue correspond to large, medium and small volumes, respectively. (c) Graph plotting the diameter of chalcopyrite against sphericity. (d) Three-dimensional heatmap for bornite phases (e) Graph plotting the diameter of bornite against sphericity.

with density difference and magmatic flow leads to the preferential emplacement of phoscorite along the edges of the intrusion (Basson et al., 2017; Giebel et al., 2019). Another possibility for the genesis of the carbonatite and phoscorite involves fractional crystallisation (Skulski et al., 1994; Veksler et al., 1998; Chakhmouradian, 2006; Milani et al., 2017a, b). Mineralogical zoning was also observed in both the Kovdor and Salmagorskii intrusions and ascribed to fractional crystallisation (Korobeinikov et al., 1998; Ivanyuk et al., 2016). This zoning indicates that the alternation of phoscorite and carbonatite layers might have indeed resulted from the intrusion of several magma pulses undergoing fractional crystallisation. The rare earth element (REE) concentrations within rock samples do not reveal correlations among major oxide compositions, coupled with the wide REE variation range for each rock type (Fig. 13). These features are consistent with the successive intrusion of compositionally distinct melt pulses, in agreement with Milani et al. (2017b). Magma immiscibility during emplacement is probably responsible for the presence of alternating banded carbonatite-phoscorite layers (Krasnova et al., 2004a,b; Giebel et al., 2019). The emplacement of carbonatite and phoscorite during several intrusion stages was also deduced for the Kovdor intrusion (Krasnova et al., 2004a). The preferential emplacement of phoscorite along the external boundaries of the Loolekop Pipe can be best attributed to density separation during an eventual rotational movement of the magma (Basson et al., 2017), facilitated by the intersection of fractures and shear zones, and the rotation of their segments relative to each other. 

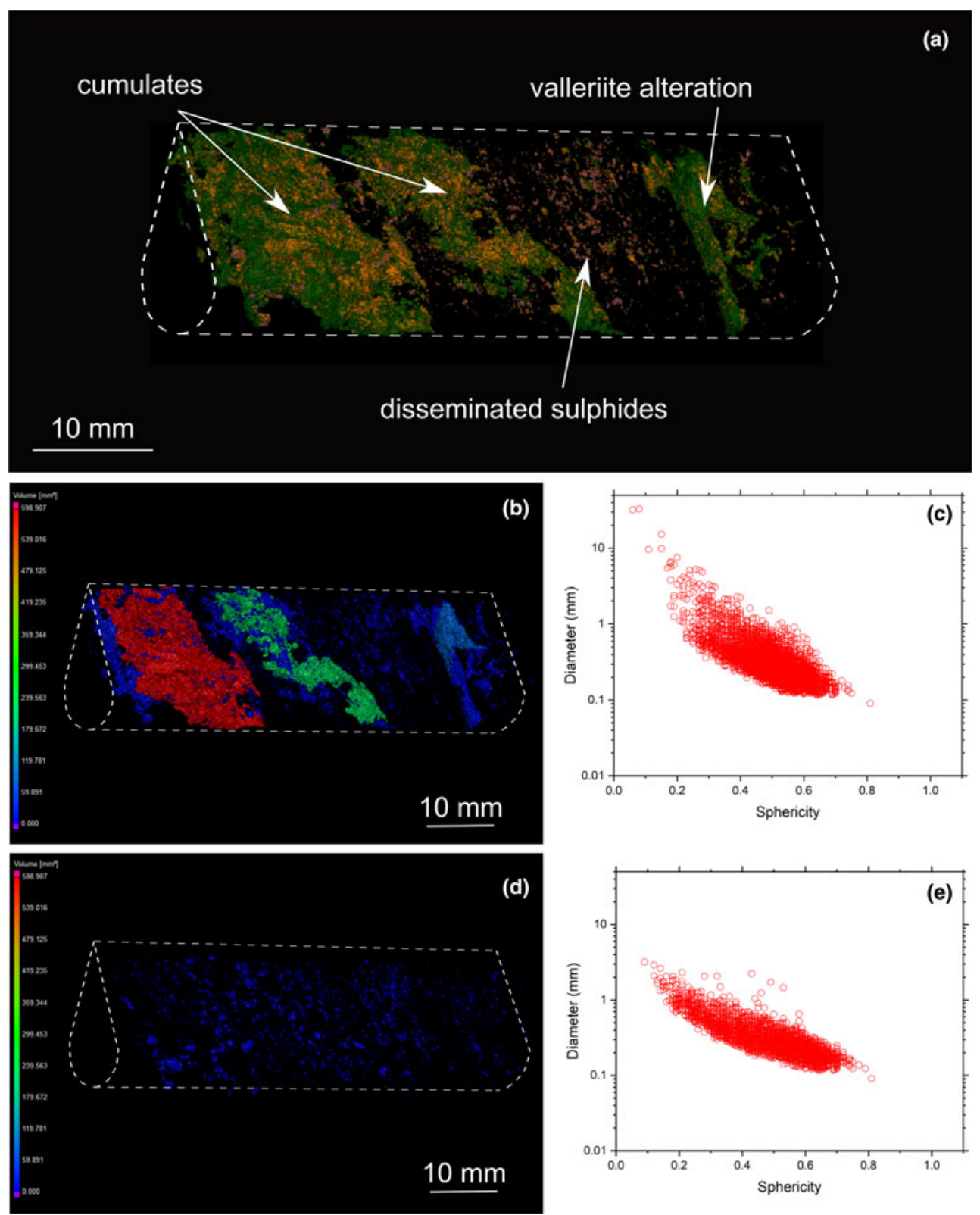

Fig. 9. (a) Three-dimensional volume rendering of drill-core sample 57 (banded carbonatite) with chalcopyrite (orange), bornite (purple) and valleriite (green) (b) Three-dimensional heatmap for chalcopyrite phases. Red, green and blue correspond to large, medium and small volumes, respectively. (c) Graph plotting the diameter of chalcopyrite versus sphericity. (d) Three-dimensional heatmap for bornite phases (e) Graph plotting the diameter of bornite versus sphericity.

Sub-vertical sulfide layers may have formed synchronously with the emplacement of the banded carbonatite and phoscorite by the intrusion of a significant number of magma pulses with variable magma flow rates.

\section{Formation of hydrothermal sulfides}

The sharp contact between chalcopyrite veins and host rock suggests the precipitation of $\mathrm{Cu}$-sulfide along fractures from a hydrothermal fluid (Fontboté et al., 2017; Yang et al., 2018) (Fig. 11, Appendix 2). The edges of hydrothermal veins can be easily distinguished from the magmatic cumulate texture, as the latter shows an intricate association with the gangue
(Fig. 11). On the basis of sulfide textures alone, a magmatic origin of the mineralisation cannot be ruled out, and might be linked to an intrusion of sulfide melt into a veinlet network produced by fracturing during the emplacement of several magma pulses. However, a hydrothermal origin of these veins was demonstrated by combined trace-element and $\mathrm{Cu}$ and $\mathrm{Fe}$ isotope systematics (Le Bras, 2020). Only one vein occurrence was observed in this investigation. This sulfide texture contrasts with disseminated and elongated $\mathrm{Cu}$-sulfide assemblages, which commonly occur along irregular contacts with the gangue (Figs 7 to 9). Planar sulfide layers can occur adjacent to the veins (Fig. 11). It is unclear if the alignment of sulfides parallel to the vein are of hydrothermal origin. The corresponding $3 \mathrm{D}$ 

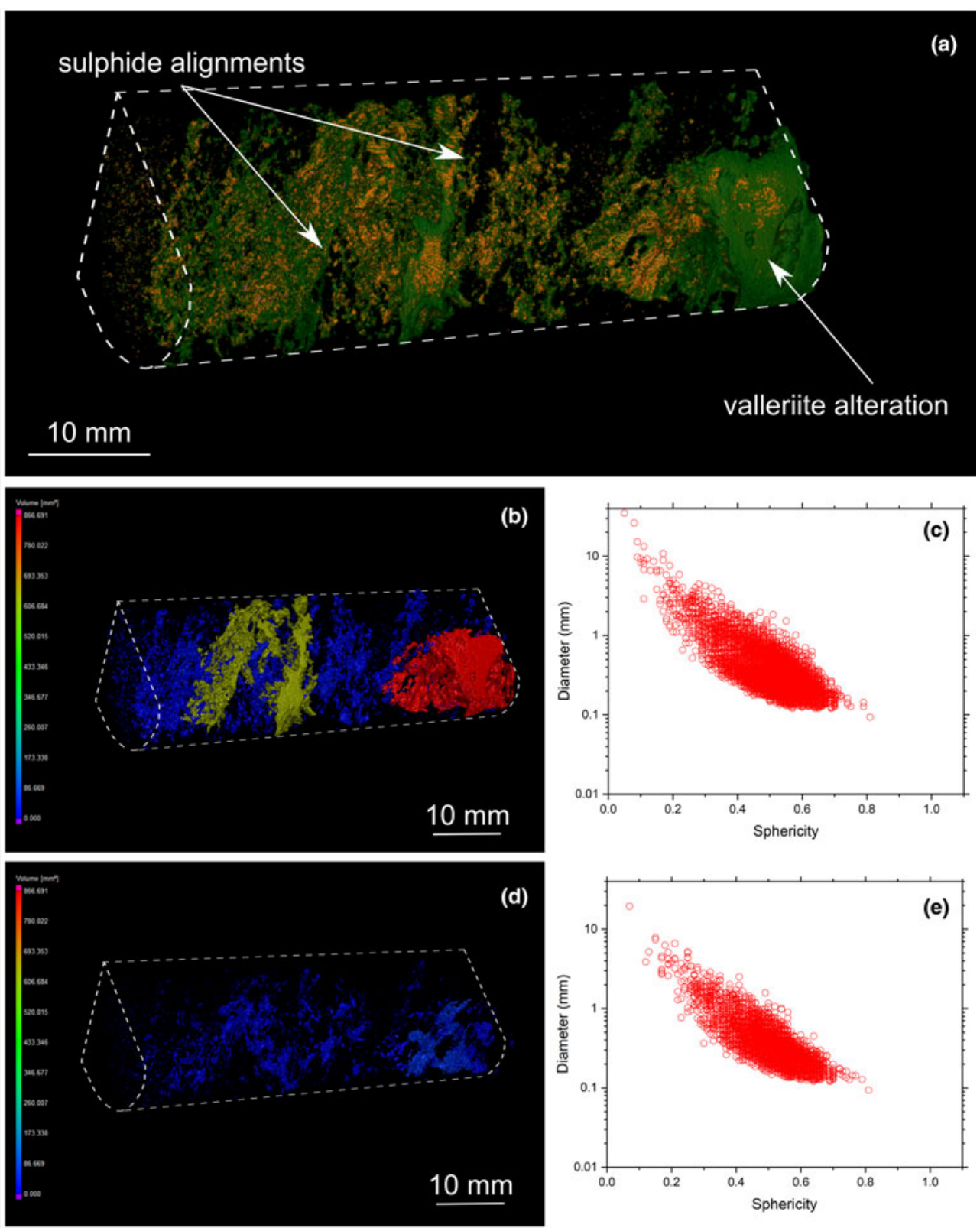

Fig. 10. (a) Three-dimensional volume rendering of drill-core sample 17 (banded carbonatite) with chalcopyrite (orange) and valleriite (green). (b) Three-dimensional heatmap for chalcopyrite phases. Red, green and blue correspond to large, medium and small volumes, respectively. (c) Graph plotting the diameter of chalcopyrite versus sphericity. (d) Three-dimensional heatmap for bornite phases (e) Graph plotting the diameter of bornite versus sphericity.

model shows no link between such alignments and the hydrothermal vein itself. The absence of disseminated grains and cumulates suggests that such preferred orientations might have resulted from the filling of fractures with sulfides within the gangue, possibly by hydrothermal fluid precipitation associated with mineral dissolution (Le Bras et al., 2021). The resolution of microCT is insufficient to allow identification of small fractures that might have acted as pathways for hydrothermal fluids within the host rock (Hoffman and De Beer, 2012). A cogenetic link between hydrothermal vein and adjacent sulfide phases, however, is a viable assumption. As suggested in a previous study (Le Bras, 2020), similar Fe isotope compositions between hydrothermal chalcopyrite and adjacent sulfide assemblage networks indicate gangue mineral dissolution by hydrothermal fluids and precipitation of sulfides into the resulting voids within the host rock along the contacts to hydrothermal mineralisation.

\section{Late-stage alteration characteristics}

Several hypotheses exist regarding the origin of valleriite within the Loolekop Pipe: (1) alteration and replacement of magmatic and hydrothermal sulfides by valleriite (Lombaard et al., 1964; Palabora Mining Company Ltd. Staff, 1976; Giebel et al., 2017; Milani et al., 2017a); (2) dissolution of magmatic and hydrothermal sulfide phases and re-precipitation of dissolved material as valleriite (Giebel et al., 2017; Milani et al., 2017b); and (3) 

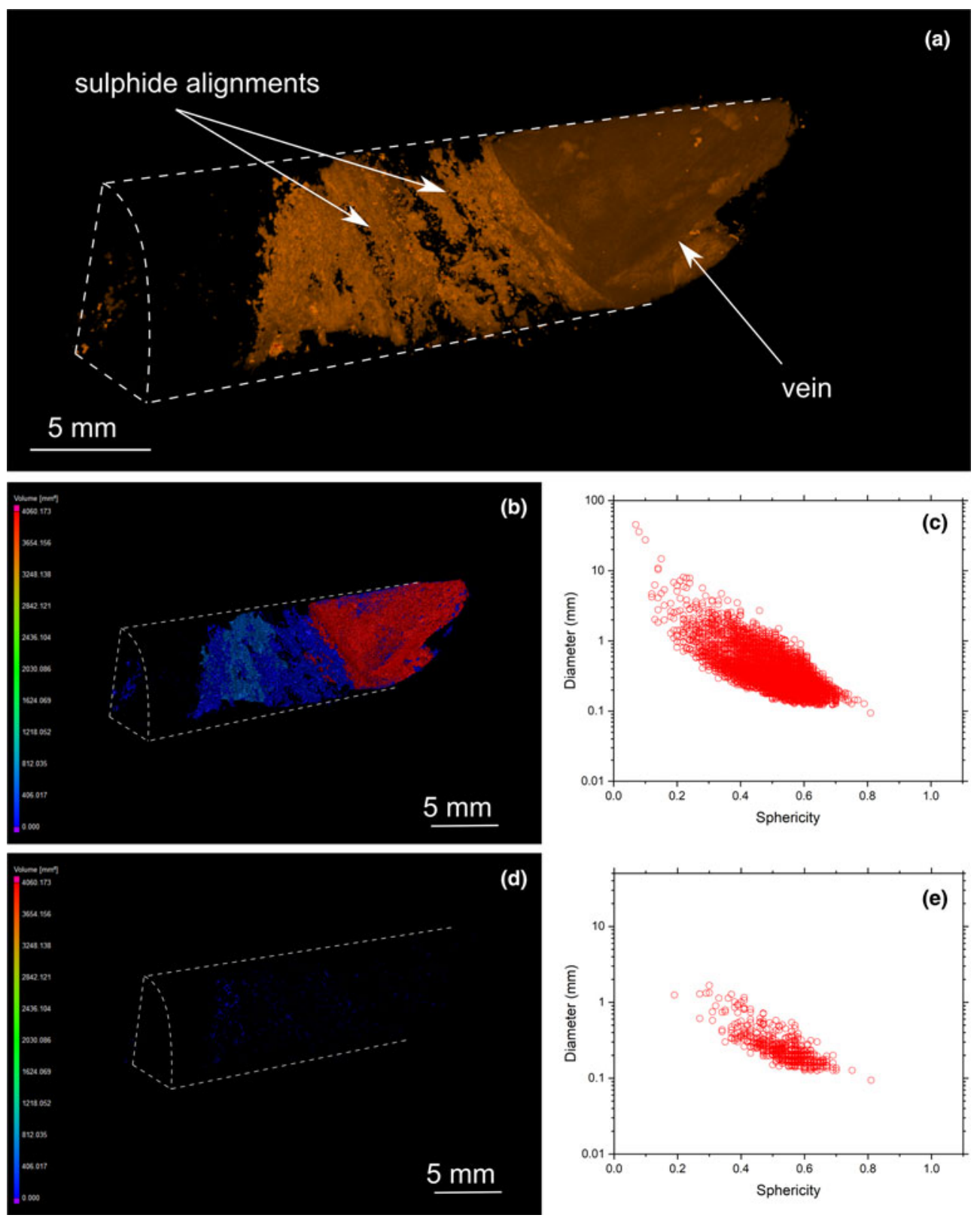

Fig. 11. (a) Three-dimensional volume rendering of drill-core sample 33 (transgressive carbonatite) with chalcopyrite (orange) and valleriite (green). (b) Three-dimensional heatmap for chalcopyrite phases. Red, green and blue correspond to large, medium and small volumes, respectively. (c) Graph plotting the diameter of chalcopyrite versus sphericity. (d) Three-dimensional heatmap for magnetite phases (e) Graph plotting the diameter of magnetite versus sphericity.

Table 1. Summary of sulfide categories and their respective textures within the Loolekop Pipe.

\section{Magmatic sulfide layers}

Small-sized $(<\mathrm{mm})$ rounded bornite and chalcopyrite Figs 5 a-e and 7 to 10 grains

Flat, elongated $\mathrm{mm}$ to $\mathrm{cm}$ chalcopyrite and bornite assemblages

Chalcopyrite mm-thick cumulates

\section{Hydrothermal veins}

$\mathrm{cm}$-wide chalcopyrite veins

Adjacent chalcopyrite-filled veinlet network

Late-stage valleriite

In veinlet across primary sulfides and at grain boundaries

In small fractures at proximity of primary sulfides
Figs $7 b, d$ and $8 b, d$

Figs $6 \mathrm{~b}, 7 \mathrm{~b}, 8 \mathrm{~b}$ and $9 \mathrm{~b}$

Figs $5 f$ and 11

Fig. 11

Figs $9 a$ and $10 a$;

Appendix 2

Fig. $5 b$ deposition of a thin valleriite film on the primary sulfides (Palabora Mining Company Ltd. Staff, 1976). The desulfurisation of primary sulfides by fluid alteration resulting in the formation of both valleriite and magnetite is our preferred explanation (Le Bras et al., 2021).

Microscopic observations and microCT analysis show alteration of magmatic sulfides by late-stage fluids, as well as their dissolution and re-precipitation in the form of valleriite along adjacent fractures (Figs 9 and 10; Appendix 2, sample 57). A dissolution-(re) precipitation cycle related to late-stage fluid circulation is possible, but valleriite might be predominantly the result of in situ magmatic sulfide alteration as shown by the dominant presence of valleriite at the external boundaries and along fractures within magmatic sulfide phases (Figs 2b, 5b, 9 and 10). Gangue-filled fractures in 

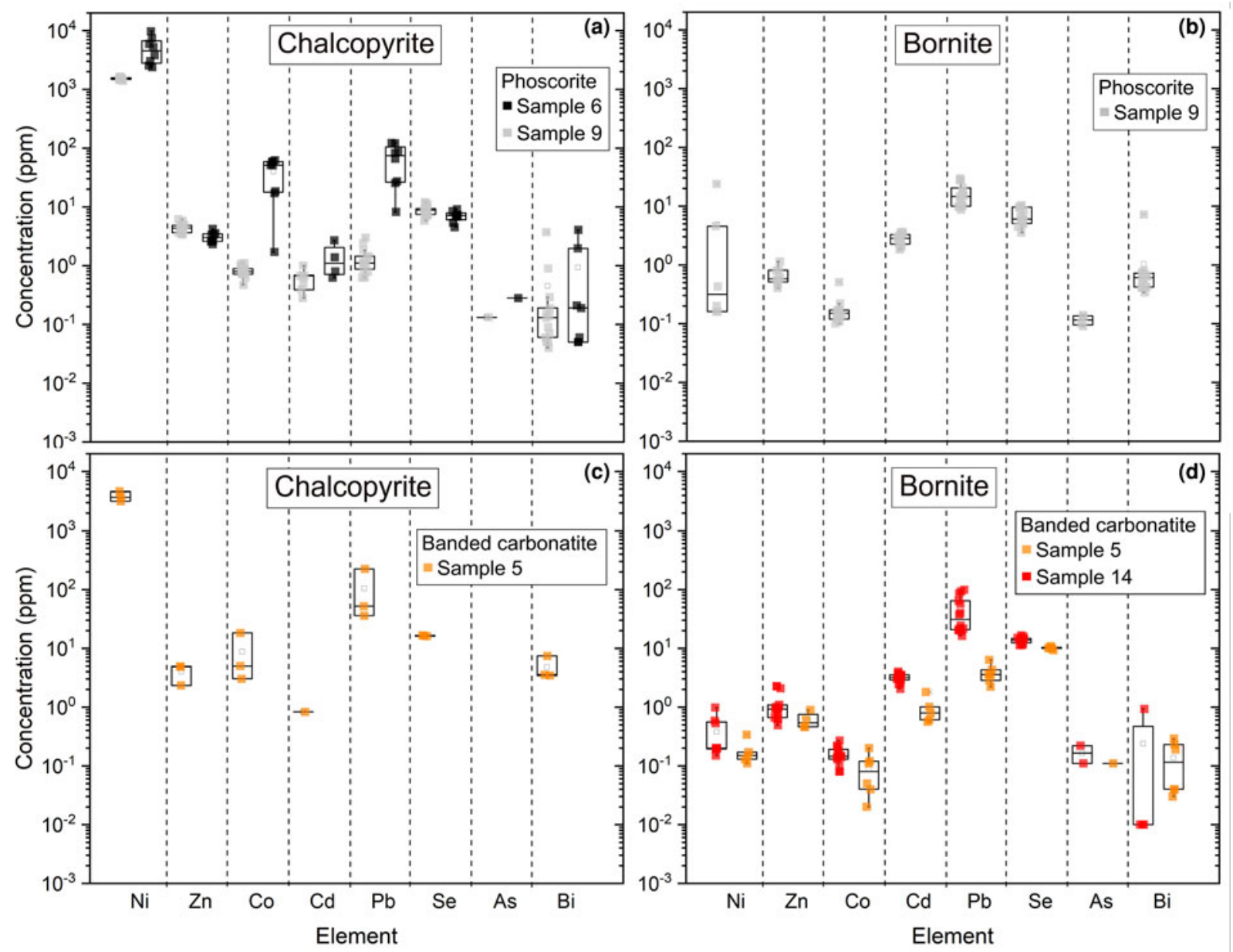

Fig. 12. Trace-element compositions by LA-ICP-MS of Cu sulfides. Data summarised from Le Bras et al. (2021).

Table 2. Trace-element composition averages for sulfide types in the samples analysed.

\begin{tabular}{|c|c|c|c|c|c|c|c|c|c|c|c|c|c|c|c|c|c|c|}
\hline Sample & Rock & Mineral & $\begin{array}{c}\mathrm{Ni} \\
(\mathrm{ppm})\end{array}$ & $n$ & $\begin{array}{c}\mathrm{Zn} \\
(\mathrm{ppm})\end{array}$ & $n$ & $\begin{array}{c}\text { Co } \\
(\mathrm{ppm})\end{array}$ & $n$ & $\begin{array}{c}\mathrm{Cd} \\
(\mathrm{ppm})\end{array}$ & $n$ & $\begin{array}{c}\mathrm{Pb} \\
(\mathrm{ppm})\end{array}$ & $n$ & $\begin{array}{c}\text { Se } \\
(\mathrm{ppm})\end{array}$ & $n$ & $\begin{array}{c}\text { As } \\
(\mathrm{ppm})\end{array}$ & $n$ & $\begin{array}{c}\mathrm{Bi} \\
(\mathrm{ppm})\end{array}$ & $n$ \\
\hline \multirow[t]{3}{*}{14} & $\mathrm{BC}$ & $\mathrm{Bn}$ & 0.38 & 8 & 1.1 & 13 & 0.15 & 14 & 3.1 & 14 & 44.4 & 14 & 13.8 & 14 & 0.16 & 2 & 0.24 & 4 \\
\hline & & $\mathrm{Cc}$ & 6.3 & 5 & 2.8 & 5 & 0.46 & 5 & 1.5 & 6 & 378.8 & 6 & 12.5 & 6 & 0.13 & 2 & $<$ LOD & 0 \\
\hline & & V & 12.6 & 3 & 10.6 & 3 & 0.59 & 3 & 13.2 & 3 & 450.3 & 3 & 8.7 & 3 & 0.98 & 3 & $<\mathrm{LOD}$ & 0 \\
\hline \multirow[t]{2}{*}{5} & $B C$ & $\mathrm{Bn}$ & 0.18 & 5 & 0.6 & 4 & 0.09 & 6 & 0.95 & 5 & 3.8 & 6 & 10.1 & 6 & 0.11 & 1 & 0.14 & 6 \\
\hline & & Ccp & 3815.2 & 3 & 4.0 & 3 & 8.77 & 3 & 0.83 & 1 & 104.1 & 3 & 16.3 & 3 & $<\mathrm{LOD}$ & 0 & 4.8 & 3 \\
\hline \multirow[t]{3}{*}{9} & PC & $\mathrm{Bn}$ & 4.9 & 6 & 0.67 & 8 & 0.17 & 14 & 2.7 & 14 & 16.3 & 14 & 6.9 & 14 & 0.12 & 4 & 1.0 & 14 \\
\hline & & Ccp & 5018.6 & 8 & 3.1 & 8 & 39.9 & 8 & 1.4 & 4 & 67.6 & 8 & 6.9 & 8 & 0.28 & 1 & 0.94 & 7 \\
\hline & & V & 235.9 & 4 & 0.98 & 4 & 3.7 & 4 & 2.1 & 4 & 101.1 & 4 & 7.2 & 4 & 0.12 & 2 & 171.9 & 4 \\
\hline 6 & PC & $\mathrm{Ccp}$ & 1516.7 & 13 & 4.4 & 13 & 0.81 & 13 & 0.6 & 7 & 1.3 & 13 & 8.8 & 13 & 0.13 & 1 & 0.45 & 13 \\
\hline
\end{tabular}

$\mathrm{Bn}=$ bornite; $\mathrm{Cc}=$ chalcocite; $\mathrm{Ccp}=$ chalcopyrite; $\mathrm{V}=$ valleriite; $\angle \mathrm{LOD}=$ below the level of detection. Data summarised from Le Bras et al. $(2021)$.

proximity to valleriite-magmatic sulfide assemblages support fluid circulation and in situ replacement of primary sulfides by valleriite. Three-dimensional images show no major fractures filled with valleriite across the host rock (Appendix 2, sample 53), suggesting both a limited dissolution-precipitation episode and rapid precipitation of the dissolved material indicating desulfurisation and replacement of magmatic sulfides by valleriite and magnetite along fractures and mineral surfaces (Mücke, 2017; Le Bras et al., 2021). The texture of valleriite supports this hypothesis (Hakris and Vaughan, 1972).
Valleriite is distributed heterogeneously among the samples. For instance, some samples are unaffected by the alteration of chalcopyrite-bornite assemblages and valleriite formation (e.g. Fig. 8). Circulation of late-stage fluids might have been facilitated by a structural event post-dating the emplacement of magmatic and hydrothermal mineralisation forming a dense fracture network (Fig. 14). The absence of fractures and veins, conversely, may not have been conducive to fluid circulation and, consequently, formation of valleriite, leaving primary sulfide assemblages essentially intact. 

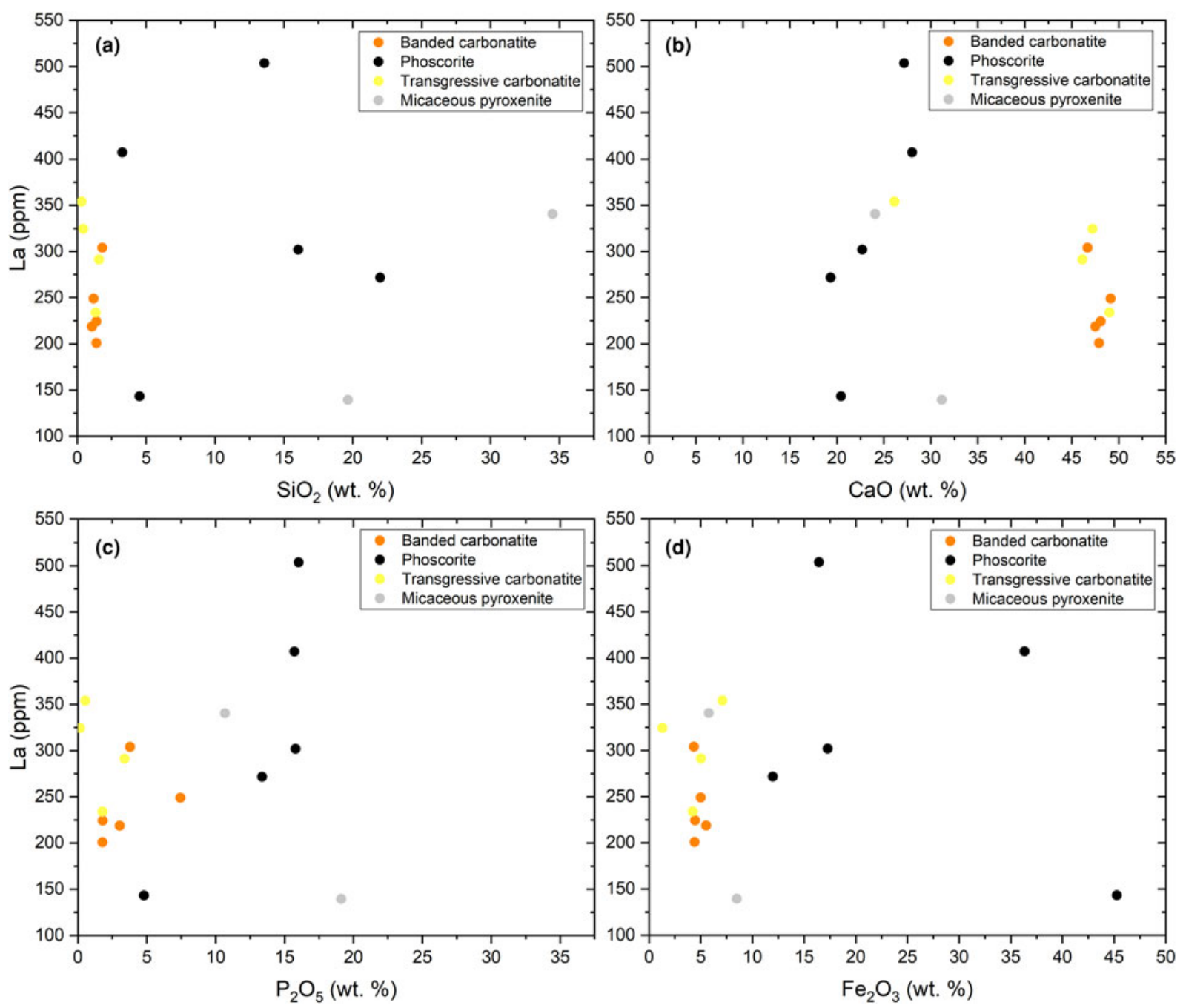

Fig. 13. Covariation of La and major oxides in banded carbonatite, phoscorite, transgressive carbonatite and micaceous pyroxenite from the Loolekop Pipe. (a) La vs. $\mathrm{SiO}_{2}$; (b) La vs. $\mathrm{CaO}$; (c) La vs. $\mathrm{P}_{2} \mathrm{O}_{5}$; and (d) La vs. $\mathrm{Fe}_{2} \mathrm{O}_{3}$. Data from Le Bras et al. (2021).

\section{Conclusions}

MicroCT analysis of several drill-core samples, representing three major rock types (phoscorite, banded and transgressive carbonatites) within the Loolekop Pipe of the Phalaborwa Igneous Complex reveal the presence of sub-vertical sulfide layers parallel to alternating phoscorite and banded carbonatite layers. These layers display three distinct textures: (1) small $(<500 \mu \mathrm{m})$ disseminated sulfides; (2) elongated flat sulfide aggregates $(>1 \mathrm{~mm})$; and (3) chalcopyrite cumulates ( $>\mathrm{mm}$ wide). The irregular and rounded surface of elongated aggregates parallel to the layer axis suggests that they formed by coalescence of sulfide grains. Modal proportions of bornite and chalcopyrite differ from one layer to another, suggesting a strong control of the mechanical sorting in the formation of the different textures of magmatic sulfide phases. The alternating distribution of banded carbonatite and phoscorite reinforce the notion that the banded carbonatite and phoscorite, as well as the sulfide layers, resulted from emplacement of several successive magma pulses. These pulses became increasingly depleted in Fe-oxides, silicates and phosphate in the course of intrusive activity. Melt immiscibility, rotation and the involvement of several magma pulses could have resulted in the formation of alternating carbonatite and phoscorite banding, as well as sub-vertical sulfide layers hosted within these two rock types. Sulfide textures formed in response to variations in magma flow rate, in sulfide liquid volume as well as changing conditions during magmatic activity. Disseminated sulfide layers might have formed from sulfide droplets under high magma flow rates, whereas elongated sulfides could have resulted from coalescence of sulfide droplets under low magma flow rates and sulfide cumulates from segregation and accumulation of sulfide liquid at the external boundaries.

High-temperature hydrothermal fluids precipitating large amounts of chalcopyrite along fractures across the Loolekop Pipe also circulated within small fracture networks adjacent to the hydrothermal vein itself, forming small-sized chalcopyrite and bornite assemblages within the host rocks (Le Bras et al., 2021). These sulfide networks are classified as disseminated grains in this study due to the size of the fractures allowing hydrothermal fluids to circulate which is below the microCT resolution.

Valleriite is derived from the alteration of pre-existing magmatic sulfides. Valleriite was not observed along fractures across the gangue 

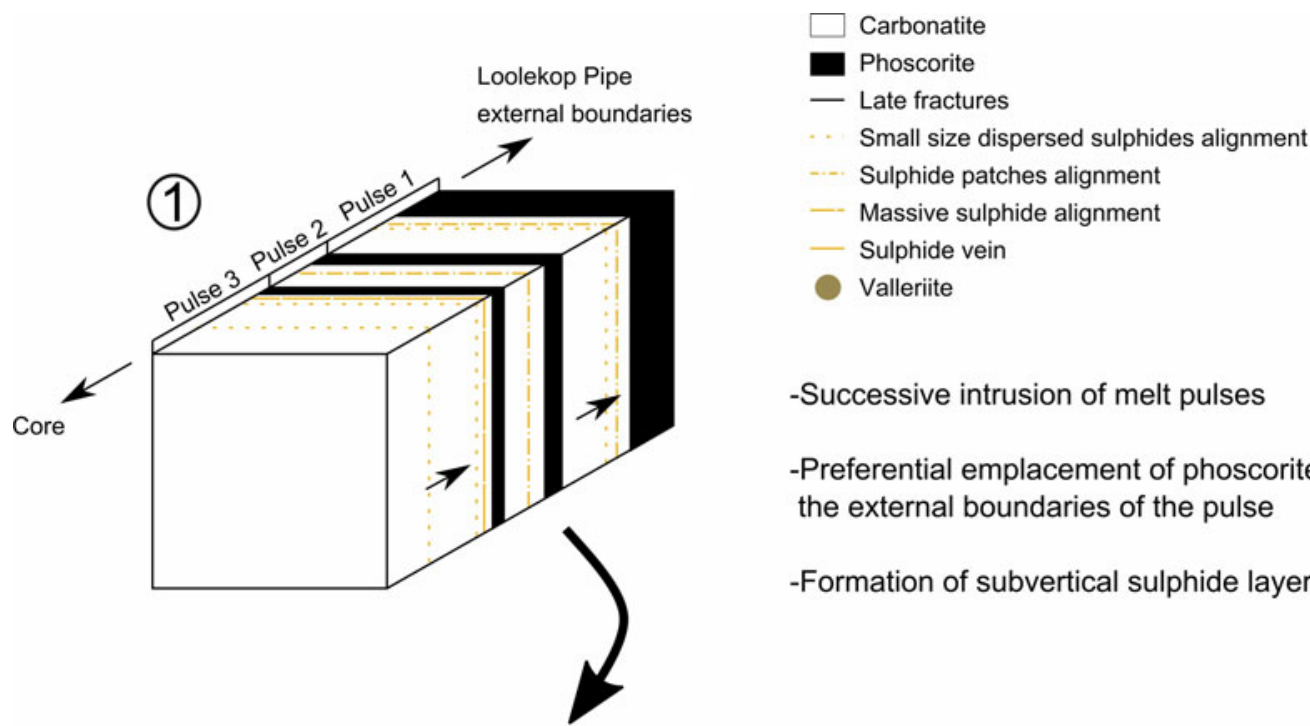

\section{-Successive intrusion of melt pulses \\ -Preferential emplacement of phoscorite at the external boundaries of the pulse}

-Formation of subvertical sulphide layers

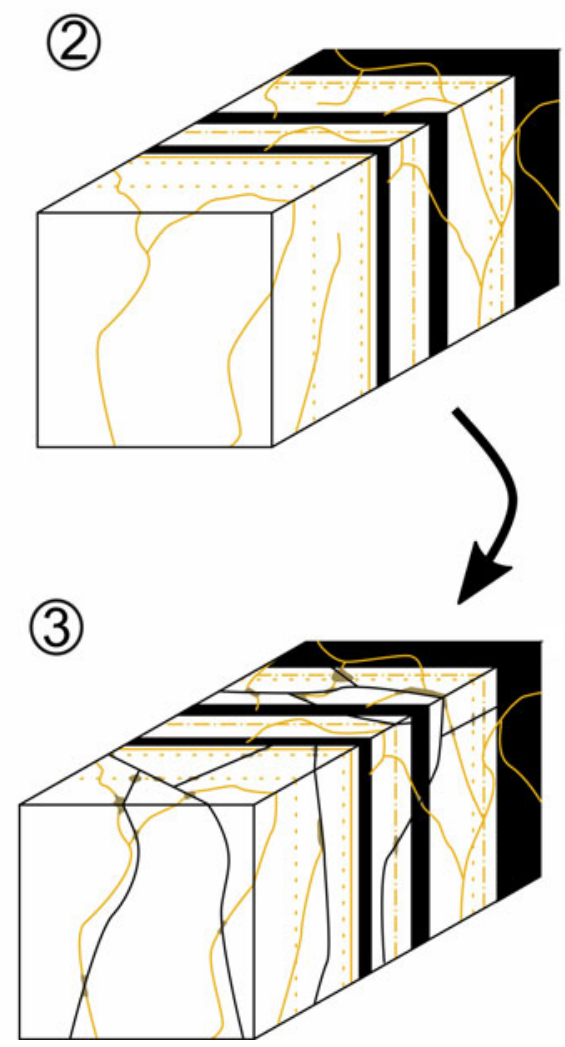

-Structural event forming a fracture network within the pipe

-Circulation of high-temperature hydrothermal fluids

-Precipitation of chalcopyrite and cubanite along the fractures

\section{-Late structural event forming a fracture network within the pipe}

-Circulation of late-stage fluids leaching the primary and hydrothermal mineralisation

-Formation of valleriite by desulphurisation of pre-existing sulphides

Fig. 14. Model of sulfide mineralisation in the Loolekop Pipe. (1) Melt pulses are sequentially emplaced, each forming phoscorite along their external boundaries and carbonatite towards the core of the intrusion as well as vertical alignments of sulfides. (2) Structural events occur during the precipitation of chalcopyrite from high-temperature hydrothermal fluids along the fractures. (3) Appearance of valleriite associated with late-stage fractures associated with chalcopyrite and bornite alignments.

in this study, indicating a limited role of dissolution / re-precipitation. The alteration is heterogeneous across the Loolekop Pipe and was probably controlled by the presence of fractures. Only sulfides in proximity to fractures were affected by late-stage alteration and valleriite formation, leaving parts of the magmatic and hydrothermal sulfide layers unaltered.

Supplementary material. To view supplementary material for this article, please visit https://doi.org/10.1180/mgm.2021.32
Acknowledgements. We thank Thabitha Moyana and Paulien Lourens from the Palabora Mining Company (PMC) for providing access to sample drillcore material. Jakobus Hoffman is acknowledged for his help during measurements and data processing. Caiphas Majola prepared and polished blocks at the University of the Witwatersrand. Professor David Good and the two anonymous reviewers are thanked for their constructive comments that have helped to improve this paper. The support of the DSI-NRF Centre of Excellence for Integrated Mineral and Energy Resource Analysis (DSI-NRF CIMERA) towards this research is hereby acknowledged. Opinions expressed, 
and conclusions arrived at, are those of the authors and are not to be attributed to the DSI-NRF CIMERA.

\section{References}

Barnes S.J., Fiorentini M.L., Austin P., Gessner K., Hough R.M. and Squelch A.P. (2008) Three-dimensional morphology of magmatic sulfides sheds light on ore formation and sulfide melt migration. Geology, 36, 655-658.

Barnes S.J., Le Vaillant M., Godel B. and Lesher C.M. (2019) Droplets and bubbles: Solidification of sulfide-rich vapour-saturated orthocumulates in the Norilsk-Talnakh Ni-Ce-PGE ore-bearing intrusions. Journal of Petrology, 60, 269-300.

Basson I., Lourens P., Paetzold H.-D., Thomas S., Brazier R. and Molabe P. (2017) Structural analysis and 3d modelling of major mineralizing structures at the Phalaborwa copper deposit. Ore Geology Reviews, 83, 30-42.

Bolhar R., Whitehouse M.J., Milani L., Magalhães N., Golding S.D., Bybee G., LeBras L. and Bekker A. (2020) Atmospherics and lithospheric Pb in sulfides from the $2.06 \mathrm{Ga}$ Phalaborwa phoscorite-carbonatite complex, South Africa. Earth and Planetary Science Letters, 530, https:doi.org// 10.1016/j.epsl.2019.115939.

Brod J.A., Junqueira-Brod T.C., Gaspar J.C., Petrinovic I.A., de Castro Valente S. and Corval A. (2013) Decoupling of paired elements, crossover REE patterns, and mirrored spider diagrams: Fingerprinting liquid immiscibility in the Tapira alkaline-carbonatite complex, se brazil. Journal of South American Earth Sciences, 41, 41-56.

Bulakh A.G., Rudashevsky N.S. and Karchevsky P.I. (1998) Gold, silver, sulfides and rare-earth minerals in carbonatites of the Loolekop Deposit (RSA). Zapiski Vserossiyskogo Mineralogicheskogo Obshchestva, 3, 45-54.

Cabri L.J. (1973) New data on phase relations in the Cu-Fe-S system. Economic Geology, 68, 443-454.

Chakhmouradian A.R. (2006) High-field-strength elements in carbonatitic rocks: Geochemistry, crystal chemistry and significance for constraining the sources of carbonatites. Chemical Geology, 235, 138-160.

Cnudde V. and Boone M.N. (2013) High-resolution X-ray computed tomography in geosciences: A review of the current technology and applications. Earth-Science Reviews, 123, 1-17.

de Bremond d'Ars J., Arndt N.T. and Hallot E. (2001) Analog experimental insights into the formation of magmatic sulfide deposits. Earth and Planetary Science Letters, 186, 371-381.

Eriksson S.C. (1982) Aspects of the Petrochemistry of the Phalaborwa Complex, Northeastern Transvaal, South Africa. PhD. University of the Witwatersrand, South Africa.

Fontboté L., Kouzmanov K., Chiaradia M. and Pokrovski G.S. (2017) Sulfide minerals in hydrothermal deposits. Elements, 13, 97-103.

Giebel R.J., Gauert C.D.K., Marks M.A.W., Costin G. and Markl G. (2017) Multi-stage formation of REE minerals in the Palabora carbonatite complex, South Africa. American Mineralogist, 102, 1218-1233.

Giebel R.J., Marks M.A.W., Gauert C.D.K. and Markl G. (2019) A model for the formation of carbonatite-phoscorite assemblages based on the compositional variations of mica and apatite from the Palabora carbonatite complex, South Africa. Lithos, 324-325, 89-104.

Godel B., Barnes S.J., Barnes S.-J. and Maier W.D. (2010) Platinum ore in three dimensions: Insights from high-resolution $\mathrm{x}$-ray computed tomography. Geology, 38, 1127-1130.

Godel B.M., Barnes S.J. and Barnes S.J. (2013) Deposition mechanisms of magmatic sulfide liquids: Evidence from high-resolution x-ray computed tomography and trace element chemistry of komatiite-hosted disseminated sulfides. Journal of Petrology, 54, 1455-1481.

Groves D.I. and Vielreicher N.M. (2001) The Phalaborwa (Palabora) carbonatite-hosted magnetite-copper sulfide deposit, South Africa: An endmember of the iron-oxide copper-gold-rare earth element deposit group? Mineralium Deposita, 36, 189-194.

Hakris D. and Vaughan D. (1972) Two fibrous iron sulfides and valleriite from Cyprus with new data on valleriite. American Mineralogist, 57, 1037-1052.

Hanekom H.J., Van Standen C.M., Smit P.J. and Pike D.R. (1965) The Geology of Palabora Igneous Complex, South Africa. Geological Survey Handbook, Memoir 54.
Heaman L.M. and LeCheminant A.N. (1993) Paragenesis and U-Pb systematics of baddeleyite $\left(\mathrm{ZrO}_{2}\right)$. Chemical Geology, 110, 95-126.

Heinrich E.W. (1970) The Palabora carbonatitic complex - a unique copper deposit. The Canadian Mineralogist, 10, 585-598.

Hoffman J.W. and De Beer F.C. (2012) Characteristics of the micro-focus X-ray tomography facility (mixrad) at Necsa in South Africa. 18th World Conference on Nondestructive Testing, Durban, South Africa.

Ivanyuk G.Y., Kalashnikov A.O., Pakhomovsky Y.A., Mikhailova J.A., Yakovenchuk V.N., Konopleva N.G., Sokharev V.A., Bazai A.V. and Goryainov P.M. (2016) Economic minerals of the Kovdor baddeleyite-apatite-magnetite deposit, Russia: Mineralogy, spatial distribution and ore processing optimization. Ore Geology Reviews, 77, 279-311.

Korobeinikov A.N., Mitrofanof F.P., Gehör S., Laajoki K., Pavlov V.P. and Mamontov V.P. (1998) Geology and copper sulfide mineralization of the Salmagorskii ring igneous complex, Kola Peninsula, NW Russia. Journal of Petrology, 39, 2033-2041.

Krasnova N.I., Balaganskaya E.G. and Garcia D. (2004a) Kovdor - classic phoscorite. Pp. 95-127 in: Phoscorites and Carbonatites from Mantle to Mine: The Key Example of the Kola Alkaline Province (A. Zaitsev, and F. Wall, editors). Mineralogical Society Series, Vol. 10. Mineralogical Society of Great Britain and Ireland, London.

Krasnova N.I., Petrov T.G., Balaganskaya E.G., Garcia D., Moutte J., Zaitsev A.N. and Wall F. (2004b) Introduction to phoscorites: Occurences, composition, nomenclature and petrogenesis. Pp. 43-72 in: Phoscorites and Carbonatites from Mantle to Mine: The Key Example of the Kola Alkaline Province (A. Zaitsev, and F. Wall, editors). Mineralogical Society Series, Vol. 10. Mineralogical Society of Great Britain and Ireland, London.

Le Bras L.Y. (2020) Insights into Sources and Ore-Forming Processes of $\mathrm{Cu}$-Sulfide Mineralization of the Phalaborwa Igneous Complex, From Coupled $\mathrm{Cu}$ and $\mathrm{Fe}$ Isotope and Trace Element Systematics. PhD. University of the Witwatersrand, Johannesburg.

Le Bras L.Y., Bolhar R., Bybee G.M., Nex P.A.M., Guy B.M., Moyana T. and Lourens P. (2021) Platinum-group and trace elements in $\mathrm{Cu}$-sulfides from the Loolekop pipe, Phalaborwa: Implications for ore-forming processes. Mineralium Deposita, 56, 161-177.

Lesher C. and Groves D. (1986) Controls on the formation of komatiite-associated nickel-copper sulfide deposits. Pp. 43-62 in: Geology and Metallogeny Of Copper Deposits. Springer.

Lombaard A.F., Ward-Able N.M. and Bruce R.W. (1964) The exploration and main geological features of the copper deposit in carbonatite Loolekop, Palabora complex. Pp. 23 in: The Geology of Some Ore Deposits in Southern Africa (S.H. Haughton, editor). Geological Society of South Africa, Johannesburg.

Mao J.W., Pirajno F., Zhang Z.H., Chai F.M., Wu H., Chen S.P., Cheng L.S., Yang J.M. and Zhang C.Q. (2008) A review of the $\mathrm{Cu}-\mathrm{Ni}$ sulfide deposits in the Chinese Tianshan and Altay orogens (Xinjiang autonomous region, NW China): Principal characteristics and ore-forming processes. Journal of Asian Earth Sciences, 32, 184-203.

Milani L., Bolhar R., Cawthorn R.G. and Frei D. (2017a) In situ LA-ICP-MS and EPMA trace element characterization of $\mathrm{Fe}-\mathrm{Ti}$ oxides from the phoscorite-carbonatite association at Phalaborwa, South Africa. Mineralium Deposita, 52, 747-768.

Milani L., Bolhar R., Frei D., Harlov D.E. and Samuel V.O. (2017b) Light rare earth element systematics as a tool for investigating the petrogenesis of phoscorite-carbonatite associations, as exemplified by the Phalaborwa complex, South Africa. Mineralium Deposita, 52, 1105-1125.

Mücke A. (2017) Review on mackinawite and valleriite: Formulae, localities, associations and intergrowths of the minerals, mode of formation and optical features in reflected light. Journal of Earth Science \& Climatic Change, 8.

Palabora Mining Company Ltd Staff (1976) The geology and the economic deposits of copper, iron, and vermiculite in the Palabora igneous complex: A brief review. Economic Geology, 71, 177-192.

Reischmann T. (1995) Precise U/Pb age determination with baddeleyite $\left(\mathrm{ZrO}_{2}\right)$, a case study from the Phalaborwa igneous complex, South Africa. South African Journal of Geology, 98, 1-4. 
Robertson J.C., Barnes S.J. and Le Vaillant M. (2015) Dynamics of magmatic sulfide droplets during transport in silicate melts and implications for magmatic sulfide ore formation. Journal of Petrology, 56, 2445-2472.

Rudashevsky N.S., Kretser Y.L., Rudashevsky V.N. and Sukharzhevskaya E.S. (2004) A review and comparison of PGE, noble-metal and sulfide mineralization in phoscorites and carbonatites from Kovdor and Phalaborwa. Pp. 363-392 in: Phoscorites and Carbonatites from Mantle to Mine: The Key Example of the Kola Alkaline Province (A. Zaitsev, and F. Wall, editors). Mineralogical Society Series, Vol. 10. Mineralogical Society of Great Britain and Ireland, London.

Schneider C.A., Rasband W.S. and Eliceiri K.W. (2012) NIH Image to ImageJ: 25 years of image analysis. Nature methods, 9, 671-675.

Skulski T., Minarik W. and Watson E.B. (1994) High-pressure experimental trace-element partitioning between clinopyroxene and basaltic melts. Chemical Geology, 117, 127-147.

Veksler I.V., Nielsen T.F.D. and Sokolov S.V. (1998) Mineralogy of crystallized melt inclusions from Gardiner and Kovdor ultramafic alkaline complexes: Implications for carbonatite genesis. Journal of Petrology, 39, 2015-2031.
Vielreicher N.M., Groves D.I. and Vielreicher R.M. (2000) The Phalaborwa (Palabora) deposit and its potential connection to iron-oxide copper-gold deposits of Olympic Dam type. Pp. 321-329 in: Hydrothermal Iron Oxide Copper-Gold \& Related Deposits: A Global Perspective (T.M. Porter, editor). Vol. 1, PGC Publishing, Adelaide, Australia.

Vukmanovic Z., Fiorentini M.L., Reddy S.M. and Godel B. (2018) Microstructural constraints on magma emplacement and sulfide transport mechanisms. Lithosphere, 11, 73-90.

Wu F.-Y., Yang Y.-H., Li Q.-L., Mitchell R.H. and Dawson J.B. (2011) In situ determination of $\mathrm{U}-\mathrm{Pb}$ ages and $\mathrm{Sr}-\mathrm{Nd}-\mathrm{Hf}$ isotopic constraints on the petrogenesis of the Phalaborwa carbonatite complex, South Africa. Lithos, 127, 309-322.

Yang X., Zhang Z., Santosh M., Li C. and Liang T. (2018) Hydrothermal copper mineralization in the Mesoproterozoic Huashugou banded iron formation, northwest China: Characteristics, timing of formation and genesis. Ore Geology Reviews, 102, 776-790.

Zieg M.J. and Marsh B.D. (2005) The Sudbury igneous complex: Viscous emulsion differentiation of a superheated impact melt sheet. Geological Society of America Bulletin, 117, 142-1450. 